Article

\title{
Recognition of Landscape Key Areas in a Coal Mine Area of a Semi-Arid Steppe in China: A Case Study of Yimin Open-Pit Coal Mine
}

\author{
Shougang Wang ${ }^{1}$, Jiu Huang ${ }^{1,2}$, Haochen Yu ${ }^{1,2, *(1)}$ and Chuning $\mathrm{Ji}^{1}$ \\ 1 School of Environment Science and Spatial Informatics, China University of Mining and Technology, \\ Xuzhou 221116, China; cumtwsg@cumt.edu.cn (S.W.); jhuang@cumt.edu.cn (J.H.); \\ jichuning@cumt.edu.cn (C.J.) \\ 2 Engineering Research Center of Mine Ecological Construction, Ministry of Education, Xuzhou 221116, China \\ * Correspondence: haochen.yu@cumt.edu.cn; Tel.: +86-185-6397-8711
}

Received: 28 December 2019; Accepted: 10 March 2020; Published: 13 March 2020

\begin{abstract}
The ecological integrity and biodiversity of steppes were destroyed under the long-term and high-intensity development of open-pit coal mines in China, causing desertification, steppe degradation, landscape function defect, and so on. As a source of species maintenance and dispersal, an ecological source is a key area for preservation in order to restore the ecological security pattern of the larger landscape. The purpose of this study was to establish a landscape key area recognition model to identify the landscape key areas (LKA) surrounding an open pit coalmine located in semi-arid steppe. This study takes the Yimin open pit mining area as a case study. We assessed Landsat 5 Thematic Mapper (TM) and Landsat 8 Operational Land Imager (OLI) remote sensing images taken during the peak season of vegetation growth from July to August in 1999, 2006, 2011, and 2017. From these images, we identified the main landscape types and vegetation coverage grades in order to identify the ecological land. Next, we applied the three indices of Importance of Patch Connectivity, Habitat Quality, and Ecosystem Service Value to calculate the comprehensive results that identify ecological land. Finally, the ecological land quality results of different years are superimposed and averaged, and then Very Important Patch (VIMP), Important Patch (IMP), and General Patch (GEP) areas were used for LKA extraction. Our results showed LKA to cover $177.35 \mathrm{~km}^{2}$, accounting for $20.01 \%$ of the total study area. The landscape types identified as LKA are primarily grassland $(47.37 \%)$, wetland $(40.27 \%)$, and shrubland $(11.88 \%)$, indicating that landscape type correlates strongly with its value as a landscape key area. The proposed landscape key area recognition model could enrich the foundations for ecological planning and ecological security pattern construction in order to support ecological protection and restoration in semi-arid steppe areas affected by coal mining.
\end{abstract}

Keywords: Landscape Key Area; ecological Source; governance; semi-arid steppe; coal mine area

\section{Introduction}

China is both the largest producer and consumer of coal in the world. The Inner Mongolia Autonomous Region occupies China's largest coal production, accounting for approximately $25 \%$ of the total output, which plays an important role in economic and social development [1]. The steppes of Inner Mongolia are representative of the grasslands of China, which have a high ecosystem service value. However, the steppe ecosystem is vulnerable to damaging effects from Inner Mongolia's open-pit coal mines, which are mostly located in arid and semi-arid areas. Opencast mining disrupts anywhere from two to eleven times more land area than underground mining [2]. Moreover, opencast mining activities often directly change the land surface and affect ecosystems both directly and indirectly 
through occupation and suppression [3-5] and can also lead to ecological and environmental problems such as land degradation, vegetation degradation [6,7], soil erosion, loss of biodiversity [4], and carbon pools [8,9]. These factors have seriously hindered the normal functioning of prairie ecosystems, leading to remarkably rapid landscape-level pattern changes [10]. In Inner Mongolia, local ecosystems have been seriously threatened by the reduced connectivity associated with landscape fragmentation caused by coal mining activities [11]. Thus, the ecological issues at both local and landscape levels associated with coal mining deserve careful investigation.

During the past decade, there has been an increasing interest in landscape pattern changes in coal mine areas [12-15]. These changes reflect a spatiotemporal evolution specific to the effects of coal mining, which might lead to the rapid degradation of its native ecosystem $[16,17]$. Previous research shows that mining activities lead to reduced farmland, landscape fragmentation [18], decreased landscape quality and stability $[19,20]$, and severely impaired ecological balance [21,22]. The construction of ecological corridors and the establishment of ecological networks are also current research concerns regarding landscape security patterns. A series of quantitative models and methods have been utilized to represent the radical disturbance of coal mining on landscape-level patterns in areas with complex terrain [23].

With the development of remote sensing (RS) technology and geographic information system (GIS), studies on landscape-level pattern changes in mine areas have achieved great progress [16,24]. Landscape metrics have been utilized in many research topics, including but not limited to examining the interplay between landscape structures and ecological functions $[25,26]$, and quantifying ecosystem services [27]. Considerable research has been conducted on the landscape-level pattern changes in coal mine areas $[23,28]$. Key aspects of landscape ecology can be identified by simulating different ecological processes, such as nodes, patches, and networks. Nevertheless, research that would enable recognition of key landscape areas is still lacking, especially for the ecologically fragile steppes associated with coal mines. Composed of grassland-area organisms and non-biological characteristics, the steppe ecosystem is a basic functional unit within the larger landscape that facilitates material circulation and energy exchange. However, it is not scientific to extract all grassland as ecological source without evaluation and screening. Currently, the majority of existing index systems select economic, social, industrial, environmental, and other statistical data based on administrative divisions that are not applicable in ecologically fragile coal mine areas with sparse population, underdeveloped economy, and in relatively small research areas. The goals of this study are to (1) construct an ecological landscape key area recognition index system for a steppe coal mine area for both spatial and temporal scales; (2) identify the landscape key areas (LKA) of a steppe coal mine area; and (3) highlight the properties of a coal mine area in a steppe region in order to provide other similar areas with a guide for recognizing LKA and optimizing ecological networks.

\section{Material and Methods}

\subsection{Study Area}

The study site is the Yimin open-pit coal mine $\left(119.650^{\circ} \mathrm{E}\right.$ to $119.764^{\circ} \mathrm{E}, 48.539^{\circ} \mathrm{N}$ to $\left.48.645^{\circ} \mathrm{N}\right)$, located in Ewenki Autonomous Banner, Hulun Buir City, Inner Mongolia Autonomous Region, China (Figure 1). Located in the eastern region of Hailar Basin on the West slope of the Greater Khingan Range, this area comprises approximately $886.24 \mathrm{~km}^{2}$. The terrain consists of a basin, hills, and mountains, with an elevation of $644-781 \mathrm{~m}$. The basin is located in the central portion of the study area, where frequent strong air exchange results in large temperature variations. The eastern and western regions of the study area are characterized by a generally high, flat topography with vegetation, artificial lakes, and residential areas interspersed across the landscape. 


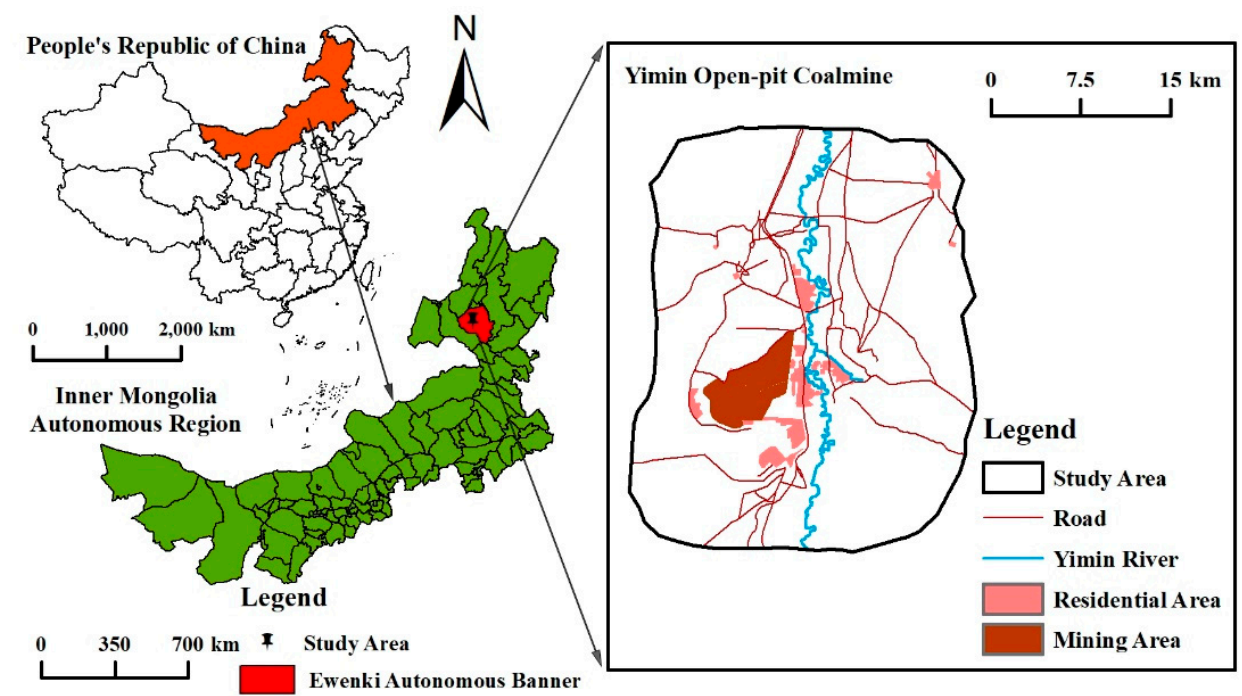

Figure 1. Location of the study area.

Owing to its deep inland location, the Yimin coal mine area is characterized by a temperate continental monsoon climate, with an annual average temperature of about $-1.9^{\circ} \mathrm{C}$. The annual precipitation ranges between 227.7 and $408.4 \mathrm{~mm}$, while the annual average evaporation ranges between 1053.2 and $1318.3 \mathrm{~mm}$. The main soil types are chestnut, alkali, meadow, swamp, and sandy. The vegetation is mainly composed of perennial herbaceous plants with approximately $50-70 \%$ coverage. The typical vegetation around the mining area is Stipa grandis and Leymus chinensis, and the banks of the Yimin River are mainly broad-leaved forests composed of deciduous trees, and the lower layer is a weed meadow. Among them, Stipa grandis is the founding species, and Leymus chinensis is the substituting species.

The recoverable raw coal reserves of Yimin Open-pit Mine are $2.3 \times 10^{9}$ tons. The design scale of coal mines has grown from $1 \mathrm{Mt} \cdot \mathrm{a}^{-1}$ in 1990 to $11 \mathrm{Mt} \cdot \mathrm{a}^{-1}$ in 2010. Open-pit coal mining has turned large-scale grazing pastures into industrial and mining land. At the same time, due to mining and dredging the surface and groundwater, the original lake in the mining area disappeared and the wetland area decreased sharply. The Yimin River and the coastal ecological environment in the east of the mining area were greatly affected.

\subsection{Data Collection}

The Yimin open-pit coal mine was opened in 2000, followed by the construction of an underground coal mine and the second phase of the open-pit mine. The vegetation growth season in the study area is from June to August, making this the optimal time period to record data on vegetative conditions. The series of Landsat 5 Thematic Mapper (TM) and Landsat 8 Operational Land Imager (OLI) data from Geospatial Data Cloud (http://www.gscloud.cn/) collected in 1999, 2006, 2011, and 2017 were carried out during the optimal window of vegetative growth in order to optimize land classification and source area identification in the study area. Image data are shown in Table 1.

Table 1. Research Data.

\begin{tabular}{ccccc}
\hline No & Data Source & Resolution & Date & Type \\
\hline 1 & LT051230261999081001T1 & $30 \mathrm{~m}$ & 1999.08 .10 & Landsat 5 TM \\
2 & LT51230262006193BJC00 & $30 \mathrm{~m}$ & 2006.07 .12 & Landsat 5 TM \\
3 & LT051230262011081101T1 & $30 \mathrm{~m}$ & 2011.08 .11 & Landsat 5 TM \\
4 & LC081230262017081101T1 & $30 \mathrm{~m}$ & 2017.08 .11 & Landsat 8 OLI \\
\hline
\end{tabular}




\subsection{Data Processing}

The overall technical route is: (1) remote sensing image pretreatment, (2) extraction of eco-logical land, (3) construction of recognition index system, and (4) recognition of landscape key area and ecological source. The technology roadmap is shown in Figure 2.

The image was cloud-free and the coordinate system was registered to the World Geodetic System 1984 (WGS 84). Radiation calibration, FLAASH atmospheric correction, image registration, and image clipping were preprocessed using the remote sensing image processing software ENVI 5.3 (Exelis Visual Information Solutions Inc., California, CA, USA). Then the remote sensing images were interpreted by ENVI 5.3 and ArcGIS 10.6 (Environmental Systems Research Institute, California, CA, USA) to obtain the main landscape type identification and vegetation coverage. Moreover, the ecological land was extracted and analyzed by FRAGSTATS 4.2 (University of Massachusetts, Amherst, Massachusetts, MA, USA).

We used three main indices in constructing our recognition model. The first, Importance of Patch Connectivity (IPC), reflects the freedom or hindrance of ecological flow between habitat patches and is a key factor in maintaining ecosystem stability and integrity [29]. The Habitat Quality (HQ) assessment is critical for biodiversity research and conservation, and an important index for recognizing ecological sources [30,31]. The Ecosystem Service Value (ESV) assessment quantifies the ecosystem's ability to provide integrated services and visually reflect the ecological benefits of the landscape [32]. Therefore, IPC, HQ, and ESV are all important indices for recognizing key landscape areas and ecological sources. Next, ESV classification was calculated by ArcGIS 10.6. IPC was evaluated by Conefor Inputs for ArcGIS 10 and Conefor Sensinode 2.2 (University of Lleida, ESP), while HQ was evaluated by InVEST 3.7 (Stanford University, California, USA \& The Nature Conservancy, Washington D.C., USA \& World Wildlife Fund, Grande, SWI).

\section{Recognition of Landscape Key Area and Ecological Source of Coal Mine Area}

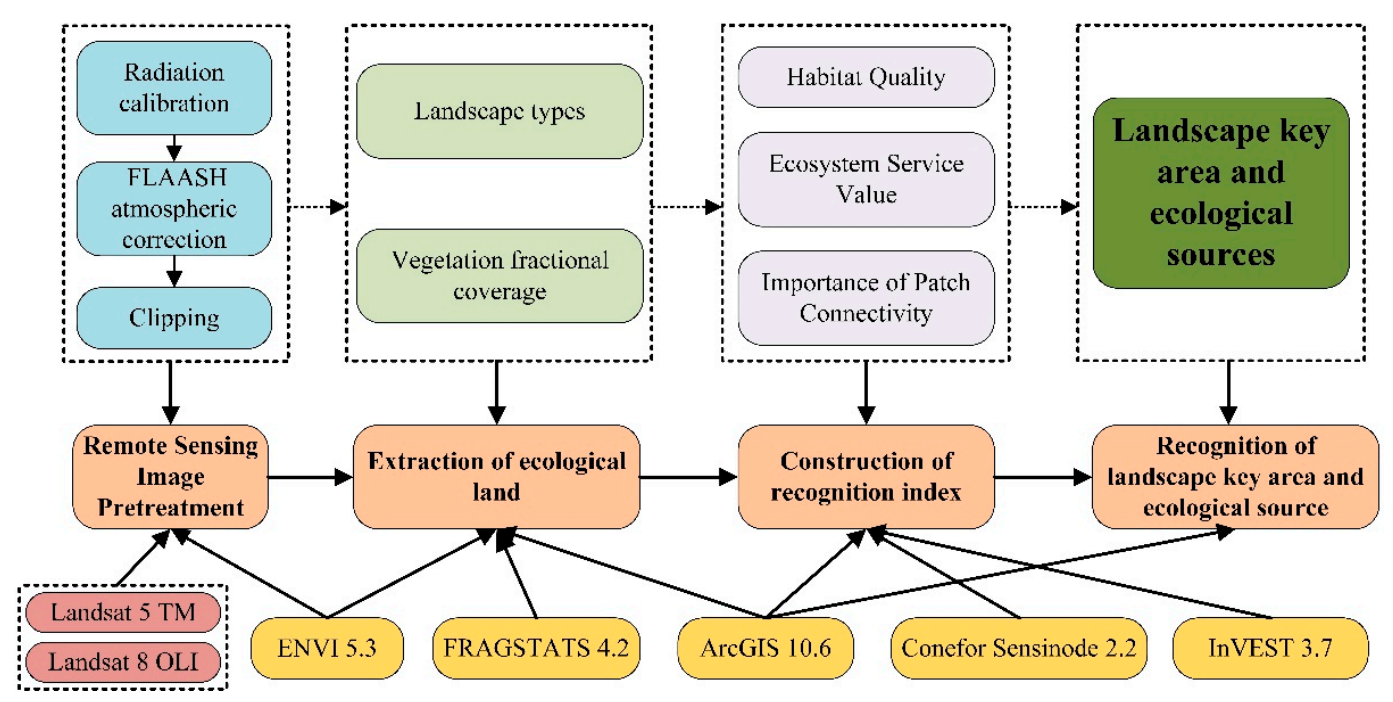

Figure 2. The technology roadmap.

\subsection{Data Analysis}

\subsubsection{Recognition and Extraction of Ecological Land}

(1) Recognition of Landscape Types

Landscape ecology is the study of the pattern and interaction between ecosystems within a region of interest, and the way the interactions affect ecological processes, especially the unique effects of 
spatial heterogeneity on these interactions [33]. Landscape ecology focuses on the role of land use types in different ways than the land-use/land-cover model (LULC), as landscape ecology principles could be used to quantify the amount and spatial distribution of land cover types and then relate them to the ecological process in question. However, the criteria for landscape type classification in coal mine area are not currently clear. Therefore, researchers generally categorize landscape types according to their own research purposes [27,34]. In order to account for the extensive damage to the landscape wrought by coal mining, including open pits and dumps, our study area was divided into eight landscape types (bare land, built-up land, mining land, grassland, shrub land, wetland, water, and road).

We concluded categories of potential landscape types via Landsat imagery, Google Earth images, and acquired land use maps. Moreover, we conducted a field survey. Some studies have found that the Random Forest Method (RF) provided the highest accuracy (86\%) [35]. Therefore, we applied the random forest algorithm for landscape classification. Supervised classification and visual correction methods were used to obtain land use maps with the support of ENVI 5.3 and ArcGIS 10.6.

\section{(2) Calculation of Vegetation Fractional Coverage}

Vegetation coverage refers to the percentage of the vertical projection area of vegetation (including leaves, stems, and branches) on the ground to the total area of the statistical area. Vegetation coverage is an important index that reflects the status of vegetation growth, as well as other complex ecological processes [36]. This is especially true in semi-arid steppe environments, where changes in vegetation coverage and other ecological changes can potentially trigger desertification [37], and other forms of environmental degradation [38]. In order to assess this important parameter, we preprocessed the Landsat TM/OLI data and then estimated the vegetation cover in the images based on the binary pixel model [39]. Vegetation coverage of the study area is measured by formula (1) and formula (2):

$$
N D V I=\frac{N I R-R E D}{N I R+R E D}
$$

where NDVI is the normalized difference vegetation index; NIR is the near infrared band; and RED is the red band; and

$$
V F C=\frac{N D V I-N D V I_{\text {soil }}}{N D V I_{\text {veg }}-N D V I_{\text {soil }}}
$$

where $V F C$ is the vegetation fractional coverage (VFC); $N D V I_{\text {soil }}$ is the minimum value of the confidence interval; and $N D V I_{\text {veg }}$ is the maximum value. The confidence interval was set to [5\%, 95\%].

\section{(3) Extraction of Ecological Land}

With China's increasing emphasis on the construction of ecological civilization, the ecological role of various types of land has also received widespread attention. Ecological land is a concept with Chinese characteristics. In this study, we define ecological land as a type of land use that provides ecosystem services [40]. We define the ecological source as a center of species dispersal and maintenance, which is essential for maintaining regional ecosystem stability. Thus, the ecological source could be regarded as the key area of ecological land. In this study, the ecological land was extracted first and then the key areas could be located. Grassland, shrubland, water, and wetlands are all extracted as ecological land.

Because the study area is located in a fragile grassland environment, serious degradation due to natural conditions and human activities could be expected [41]. Owing to the reduced vegetation coverage in heavily degraded areas, we were not able to extract all grassland areas as ecological land [42]. Therefore, the vegetation coverage was selected to be $60-100 \%$ when extracting grassland. As images were screened for ecological land, patches smaller than 1 ha were removed because their area is too small to support the survival and spread of species and to impact on the overall landscape ecosystem process. 
FRAGSTATS is a program for quantifying landscape structure [43]. The landscape pattern index of extracted ecological land was calculated by FRAGSTATS 4.2 software, and the changes of ecological land in the research period were analyzed from the perspective of landscape ecology. Moreover, Total Area (TA), Number of patches (NP), Patch Density (PD), Largest Patch Index (LPI), Landscape Shape Index (LSI), Splitting Index (SPLIT), Aggregation Index (AI), Contagion Index (CONTAG), and Interspersion Juxtaposition Index (LJI) were selected to analyze the landscape pattern in the study area. Furthermore, the definition and description of these indices has been given by the FRAGSTATS user's guide [44].

\subsubsection{Construction of Ecological Landscape Key Area Recognition Index Model}

\section{(1) Assessment of Habitat Quality (HQ)}

The HQ is a function of the landscape type within a given grid cell, along with that of the surrounding grid cells, and the sensitivity of the habitat in the focal grid cell to threats posed by the surrounding landscape [30,31]. HQ was calculated combining information on landscape types and threats to biodiversity. The equation is shown in formula (3):

$$
Q_{x j}=H_{j}\left(1-\frac{D_{x j}^{2}}{D_{x j}^{2}+k^{2}}\right)
$$

where $Q_{x j}$ is the HQ in grid cell $x$ that is in landscape type $j$, while $H_{j}$ represents habitat suitability, and $D_{x j}$ is the total threat level in grid cell $x$ within habitat type $j$. The half-saturation constant $k$ is equal to 0.5 in this study. The detailed evaluation procedure of $\mathrm{HQ}$ can be found in the literature [45].

Some input parameters for the InVEST model were determined from the literature [46,47] in the field of regional ecological assessment as described in China's National Key Research and Development Program, "Ecological restoration and protection in typical vulnerable ecological regions." The following parameters were input into the InVEST model: current landscape cover, threat raster dataset, threats data (Table 2), sensitivity of landscape types to each threat (Table 3), and half-saturation constant.

Table 2. Threats Data.

\begin{tabular}{cccc}
\hline Threat & Maximum Effective Distance $\mathbf{( k m )}$ & Weight & DECAY \\
\hline Road & 1.0 & 0.5 & Linear \\
Built-up land & 2.0 & 0.7 & Exponential \\
Mining land & 3.0 & 1.0 & Exponential \\
Bare land & 1.0 & 0.8 & Linear \\
\hline
\end{tabular}

Table 3. Sensitivity of landscape types to each threat.

\begin{tabular}{cccccc}
\hline Landscape Type & Habitat & Bare Land & Construction Land & Mining Land & Road \\
\hline Grassland & 0.8 & 0.5 & 0.7 & 0.6 & 0.4 \\
Shrub Land & 0.7 & 0.2 & 0.4 & 0.5 & 0.3 \\
Wetland & 0.9 & 0.4 & 0.5 & 0.6 & 0.4 \\
Water & 0.6 & 0.5 & 0.9 & 1.0 & 0.8 \\
Bare Land & 0.0 & 0.0 & 0.0 & 0.0 & 0.0 \\
\hline
\end{tabular}

The HQ maps were obtained after running the InVEST model with grid resolution set to $30 \mathrm{~m}$, consistent with remote sensing data. The HQ of the ecological land was identified and divided into 4 levels by the natural discontinuous point classification method. Grades 1 to 4 represent HQ from low to high. 
(2) Assessment of Ecosystem Service Value (ESV)

The ESV is an estimate of ecosystem services and natural capital using economic laws. Costanza's approach to estimating ESV is widely used [32,48]. As land use pattern is the most important factor in the supply of ecosystem services, we utilized the Landsat 5 TM and Landsat 8 OLI remote sensing data to assess changes in ESV over temporal and spatial scales.

The ecological service function is in linear proportion to biomass. The biomass-based ESV adjustment method is shown in formula (4), with a correction factor of 0.44 for determining grassland biomass in Inner Mongolia [49]. Nine indicators of ESV were selected and divided into four categories [48]: supply service (food supply, raw supply); regulation service (atmospheric regulation, climate regulation, hydrological regulation, waste disposal, and soil conservation); support service (biodiversity); and cultural service (landscape aesthetics) [50].

$$
P_{i j}=\frac{b_{j}}{B_{j}} \times P_{i}
$$

where the variable $i$ indicates the type of $\operatorname{ESV}(i=1,2,3 \ldots 9)$, while $j$ denotes the type of ecosystem; $P_{i j}$ is the revised ESV in value type $i$ that is found in ecosystem type $j$; and $B_{j}$ is average biomass per unit area in ecosystem type $j$, while $b_{j}$ is the total biomass in ecosystem type $j$.

Using these categories, we were able to evaluate and analyze the ESV for different landscape types in the study areas. The ESV in waters, grasslands, woodlands, and wetlands were assigned a grade of $1-4$ in order to designate patches of ecological land.

(3) Assessment of Importance of Patch Connectivity (IPC)

Landscape connectivity refers to the extent to which the landscape promotes or hinders species' movement between habitat patches, and it plays an important role in ecosystem services, protection of animal and plant gene communication, and landscape planning. Landscape connectivity is the degree of connectivity between each ecological patch, and the probability of connectivity (PC) is the overall index used for measuring the flow of ecological processes between patches [29]. PC represents the possibility of connectivity between patches $(0<\mathrm{PC}<1)$, and the value of $\mathrm{PC}$ is related to the distance between patches. The higher the PC value, the greater the possibility of landscape connectivity.

The Probability of Connectivity for each patch (dPC) was an index of patch importance. The dPC could be used to determine the extent to which a patch could influence the connectivity of the study area [51]. Moreover, it was applied to evaluate the importance of individual patches as connectivity providers [52]. Then the dPC could be calculated from the percentage of the variation in PC caused by the removal of each individual element from the landscape [53]. So, the influence and effect of patch on landscape connectivity could be analyzed. The higher the dPC value, the higher the Importance of Patch Connectivity (IPC) in landscape with outside.

Conefor is a software package that allows quantifying the importance of habitat areas and links for the maintenance or improvement of connectivity, as well as evaluating the impacts on connectivity of habitat and landscape changes [54]. The connection distances and nodes text file between patches were calculated by the Conefor Inputs for ArcGIS 10.6 module. The evaluation of the optimal threshold distance and the classification of functional types could be achieved by statistical methods [51]. Results were then imported into Conefor Sensinode 2.2 to calculate dPC. The calculation of PC and dPC is given in formula (5) and formula (6), respectively.

$$
P C=\frac{\sum_{i=1}^{n} \sum_{j=1}^{n} a_{i} \cdot a_{j} \cdot P_{i j}^{*}}{A_{I}^{2}}
$$


where $n$ is the number of the patches of the ecological land. $a_{\mathrm{i}}$ and $a_{\mathrm{j}}$ represent the areas of patch $i$ and $j$, respectively. $P_{i j}{ }^{*}$ represents the probability of direct dispersal of species in patches $i$ and $j . A_{I}$ is the maximum landscape attribute; when the patch attribute is habitat area, $A_{I}$ corresponds to the total landscape area of the ecological land.

$$
d P C=\frac{P C-P C_{\text {remove }}}{P C}
$$

where $P C_{\text {remove }}$ is the probability of connectivity after removal of a single patch.

The dPC value reflects the relative importance of each patch in measuring PC, and is of great significance for patch grading recognition. Natural Breakpoint Method is a commonly used classification method in ArcGIS 10.6, which could best group similar values and distinguish values with large differences, so that each group of data has strong internal correlation and large external difference. Moreover, the APC value of each patch is graded on a scale of 1-4 by the natural breakpoint method. A larger dPC value corresponds to a higher connectivity level, and therefore the IPC of the patch.

\section{(4) Recognition Landscape Key Area and Ecological Source}

Using the grid calculator function of ArcGIS, equal weights are given to IPC, HQ, and ESV in constructing the comprehensive quality evaluation maps of patches (CQEMP) for 1999, 2006, 2011, and 2017.

In order to designate an area as an ecological source, its ecology must be relatively stable for a certain period of time. Therefore, it is necessary to recognize the ecological source on both spatial and temporal scales. In order to do so, the CQEMPs for 1999, 2006, 2011, and 2017 are superimposed and graded. The grading criteria are as follows: (1) Very Important Patch (VIMP): the CQEMP of the ecological patches are all in the top $25 \%$ in all four years; or the CQEMP of the ecological patches are in the top $25 \%$ in three years and in the top $25-50 \%$ for the fourth. (2) Important Patch (IMP): the CQEMP of ecological patches are in the top $25 \%$ in two of the years and in the top $25-50 \%$ for the other two years; or the CQEMP of the ecological patches are in the top 25-50\% in three of the years and in the top $25 \%$ for the fourth. (3) General Patch (GEP): the CQEMP of the ecological patches are in the top $25-50 \%$ for all four years. (4) Not Important Patch (NIMP): All remaining patches. By extracting VIMP, IMP, and GEP as ecological sources, the final ecological recognition results were obtained.

\section{Results}

\subsection{Ecological Land}

(1) Landscape Classification

The research area landscape was divided into eight categories (see Figure 3 and Table 4), with the overall accuracy exceeded 84\%. For the entire study period from 1999 to 2017, the landscape type changes showed significant regional distribution characteristics. The area of land occupied by the mine steadily increased from 1999 to 2017. The area of built-up land and road also increased during the same period. In contrast, the bare land area decreased from 1999 to 2006, and from 2011 to 2017, while increasing from 2006 to 2011.

The area of water and shrubland changed little from 1999 to 2017, while the area of grassland decreased in total area, from $627.25 \mathrm{~km}^{2}$ to $531.10 \mathrm{~km}^{2}$. Distributed mainly over the western and northeastern regions, grassland is the largest landscape type, accounting for more than half of the study area. The wetlands are mainly distributed near the Yimin River Basin. Throughout the entire study period, the variation of the wetland area was large, increasing by $40.08 \mathrm{~km}^{2}$ from 1999 to 2006, and $9.58 \mathrm{~km}^{2}$ from 2011 to 2017, while decreasing by $13.76 \mathrm{~km}^{2}$ from 2006 to 2011. 

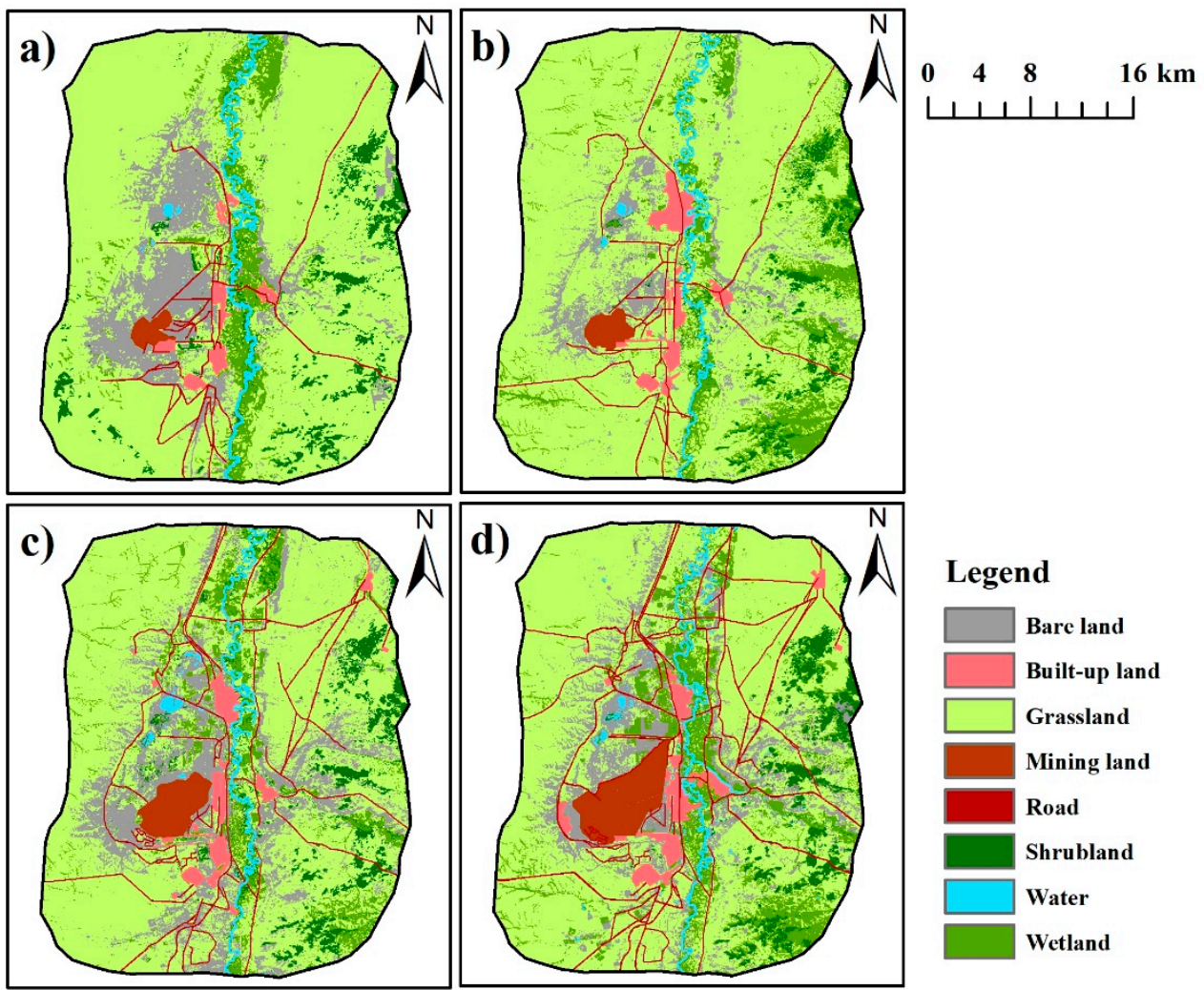

Figure 3. The main landscape types in 1999 (a), 2006 (b), 2011 (c), and 2017 (d).

Table 4. Statistical information for area $\left(\mathrm{km}^{2}\right)$ of main landscape types in 1999, 2006, 2011, and 2017.

\begin{tabular}{ccccccccc}
\hline & \multicolumn{2}{c}{$\mathbf{1 9 9 9}$} & \multicolumn{2}{c}{$\mathbf{2 0 0 6}$} & \multicolumn{2}{c}{$\mathbf{2 0 1 1}$} & \multicolumn{2}{c}{$\mathbf{2 0 1 7}$} \\
\cline { 2 - 8 } & Area & Percentage & Area & Percentage & Area & Percentage & Area & Percentage \\
\hline Grassland & 627.25 & $70.78 \%$ & 641.57 & $72.39 \%$ & 692.07 & $78.09 \%$ & 531.10 & $59.93 \%$ \\
Shrubland & 43.53 & $4.91 \%$ & 27.73 & $3.13 \%$ & 59.19 & $6.68 \%$ & 36.13 & $4.08 \%$ \\
Wetland & 60.44 & $6.82 \%$ & 100.52 & $11.34 \%$ & 86.76 & $9.79 \%$ & 96.34 & $10.87 \%$ \\
Water & 8.98 & $1.01 \%$ & 6.83 & $0.77 \%$ & 13.76 & $1.55 \%$ & 13.13 & $1.48 \%$ \\
Mining land & 6.18 & $0.70 \%$ & 8.48 & $0.96 \%$ & 22.75 & $2.57 \%$ & 30.91 & $3.49 \%$ \\
Built-up land & 11.17 & $1.26 \%$ & 19.93 & $2.25 \%$ & 24.39 & $2.75 \%$ & 29.94 & $3.38 \%$ \\
Road & 7.13 & $0.80 \%$ & 9.81 & $1.11 \%$ & 21.07 & $2.38 \%$ & 23.78 & $2.68 \%$ \\
Bare land & 121.56 & $13.72 \%$ & 71.37 & $8.05 \%$ & 192.11 & $21.68 \%$ & 124.92 & $14.10 \%$ \\
\hline
\end{tabular}

\section{(2) Vegetation Fractional Coverage}

The vegetation fractional coverage of the study area was evaluated and divided into 5 categories (see Figure 4 and Table 5). The landscape types with high VFC area (60-100\%) are largely wetland, shrubland, and some grassland. High VFC area was maximal in $2006(44.76 \%)$, followed by 2011 (44.60\%), 2017 (40.19\%) and 1999(36.09\%). Low VFC area (0-40\%) was the highest in $2011(40.38 \%)$, followed by 2017 (36.68\%), 1999 (36.67\%), and reaching a low in 2006 (22.62\%). Meanwhile, the high VFC area is mainly distributed in the southeast of the study area, and the low VFC area is mainly distributed in the mining area. The interannual variation of VFC in the northwest grassland of the study area is large. 

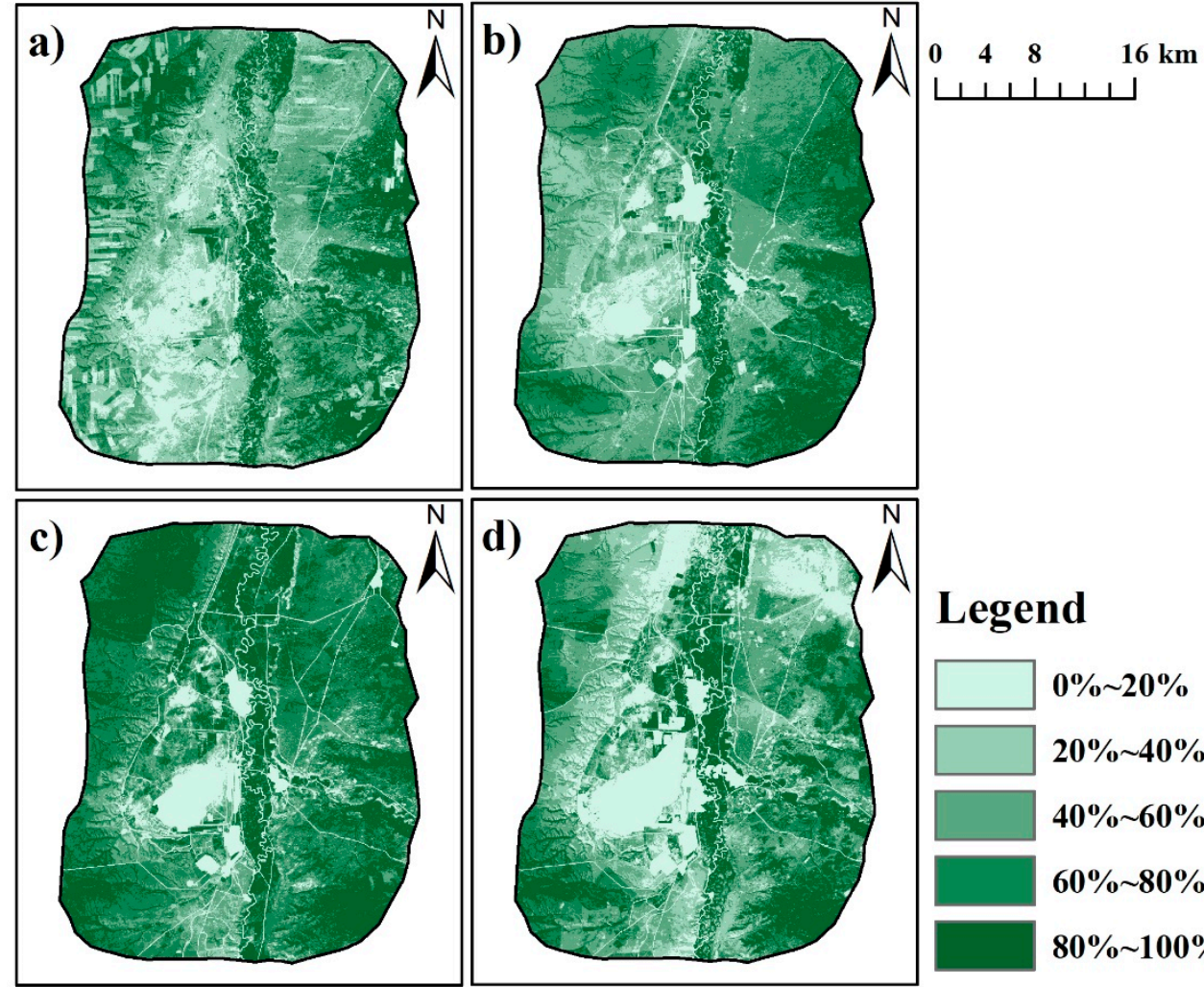

\section{Legend}

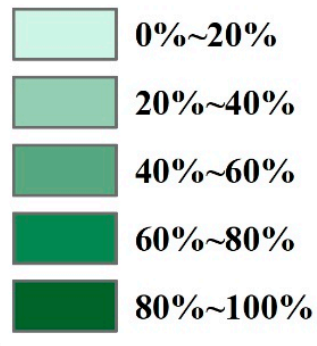

Figure 4. The vegetation fractional coverage in 1999 (a), 2006 (b), 2011 (c), and 2017 (d).

Table 5. Statistics information of vegetation fractional coverage in 1999, 2006, 2011, and $2017\left(\mathrm{~km}^{2}\right)$.

\begin{tabular}{ccccccccc}
\hline & \multicolumn{2}{c}{$\mathbf{1 9 9 9}$} & \multicolumn{2}{c}{$\mathbf{2 0 0 6}$} & \multicolumn{2}{c}{$\mathbf{2 0 1 1}$} & \multicolumn{2}{c}{$\mathbf{2 0 1 7}$} \\
\cline { 2 - 8 } & Area & Percentage & Area & Percentage & Area & Percentage & Area & Percentage \\
\hline $0-20 \%$ & 109.07 & $12.31 \%$ & 76.11 & $8.59 \%$ & 109.21 & $12.32 \%$ & 179.67 & $20.27 \%$ \\
$20-40 \%$ & 215.89 & $24.36 \%$ & 124.36 & $14.03 \%$ & 248.68 & $28.06 \%$ & 145.42 & $16.41 \%$ \\
$40-60 \%$ & 241.43 & $27.24 \%$ & 289.09 & $32.62 \%$ & 133.09 & $15.02 \%$ & 204.94 & $23.12 \%$ \\
$60-80 \%$ & 143.10 & $16.15 \%$ & 223.27 & $25.19 \%$ & 176.61 & $19.93 \%$ & 169.92 & $19.17 \%$ \\
$80-100 \%$ & 176.74 & $19.94 \%$ & 173.41 & $19.57 \%$ & 218.65 & $24.67 \%$ & 186.29 & $21.02 \%$ \\
\hline
\end{tabular}

\section{(3) Ecological Land}

The ecological land in the study area was extracted combine with the assessment results of landscape type and vegetation coverage. Then we used FRAGSTATS 4.2 software to calculated the landscape pattern index of extracted ecological land. The change in ecological land area is shown in Table 6 and Figure 5. The Total Area (TA) of ecological land changed relatively little from 1999 to 2016 , with an overall increase of $23.72 \mathrm{~km}^{2}$. Within this time, the area of ecological land increased by $96.92 \mathrm{~km}^{2}$ and $13.15 \mathrm{~km}^{2}$ from 1999 to 2006 and 2011 to 2017, respectively, and decreased from 2006 to 2011 by $86.35 \mathrm{~km}^{2}$. The Number of patches (NP), Patch Density (PD), and Largest Patch Index (LPI) as ecological land fluctuated from 1999 to 2017, showing a decreasing trend overall. Thereinto, the LPI decreased from $17.66 \%$ to $9.75 \%$, indicating the cracking and reduction of large giant patches in the study area. Moreover, the Landscape Shape Index (LSI) increased from 84.63 to 101.42, indicating that patch shape irregularity was serious. The Splitting Index (SPLIT) increased from 17.72 in 1999 to 45.52 in 2017, which directly reflects the increasing fragmentation of landscape space and the increasing impact of human activities on the ecosystem. The Aggregation Index (AI) decreased from $84.26 \%$ in 1999 to $76.98 \%$ in 2017, indicating that the dispersion degree of different types of patches in the landscape decreased. The Contagion Index (CONTAG) was high in 1999 (61.17\%), indicating that the dominant plaque type with high connectivity existed in the study area. However, the CONTAG 
value decreased to $52.41 \%$ in 2017 , indicating that the plaque fragmentation in the study area was serious, the original dominant plaque type was broken, and the spatial advantage was greatly reduced. The Interspersion Juxtaposition Index (LJI) fluctuated from 1999 to 2017, showing a decreasing trend overall. It indicates that the proximity between patches decreased in the study area. The results show that the landscape pattern of the ecological land in the study area is changing towards fragmentation. Therefore, it is necessary to further analyze the existing ecological land and identify the landscape key areas.

Table 6. Overall landscape pattern index of ecological land in 1999, 2006, 2011, and 2017.

\begin{tabular}{ccccc}
\hline Year & $\mathbf{1 9 9 9}$ & $\mathbf{2 0 0 6}$ & $\mathbf{2 0 1 1}$ & $\mathbf{2 0 1 7}$ \\
\hline TA $\left(\mathrm{km}^{2}\right)$ & 300.93 & 397.85 & 311.50 & 324.65 \\
NP $(\#)$ & 7110 & 5595 & 8001 & 6229 \\
PD (\#/100 ha) & 23.63 & 14.06 & 25.69 & 19.19 \\
LPI (\%) & 17.66 & 12.68 & 16.89 & 9.75 \\
LSI & 84.63 & 109.42 & 117.86 & 101.42 \\
SPLIT & 17.72 & 23.67 & 28.29 & 45.52 \\
AI (\%) & 84.26 & 79.62 & 76.99 & 76.98 \\
CONTAG (\%) & 61.17 & 59.40 & 53.75 & 52.41 \\
LJI (\%) & 72.66 & 43.65 & 59.35 & 47.67 \\
\hline
\end{tabular}

TA

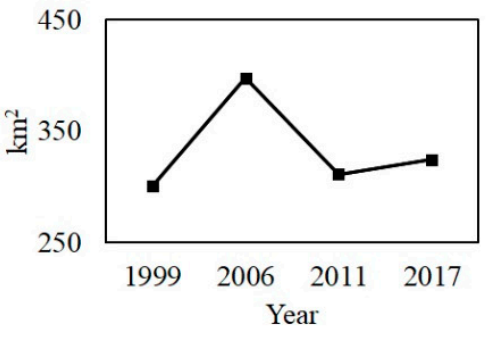

LPI

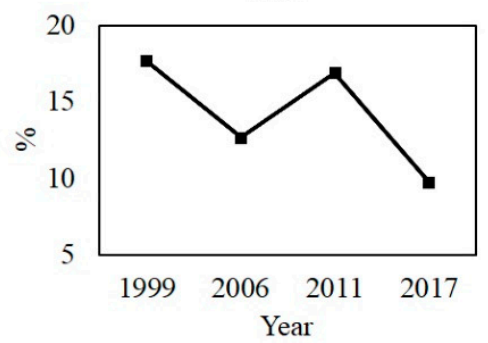

AI

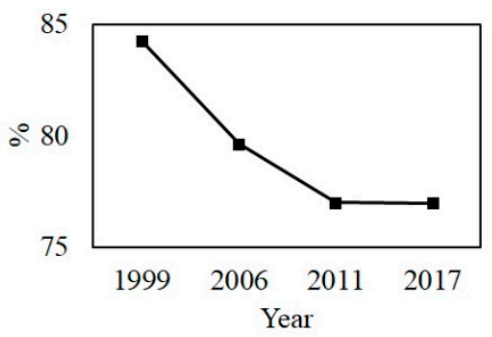

NP

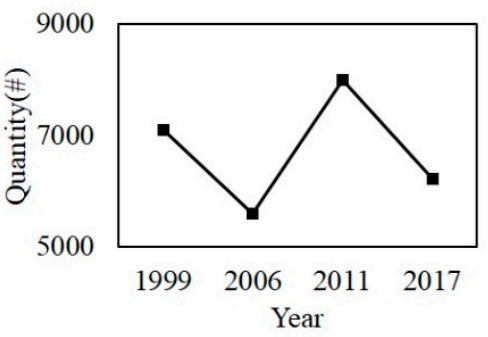

LSI

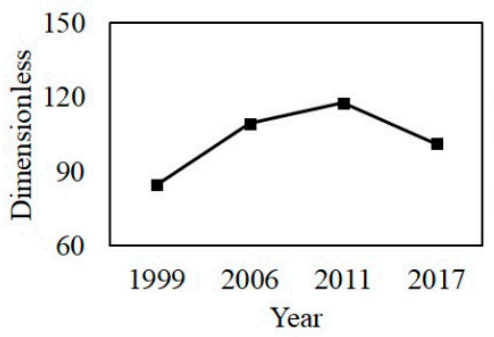

CONTAG

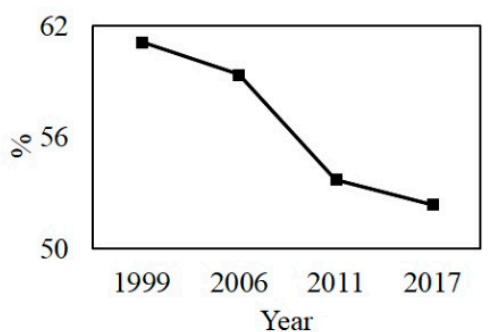

PD

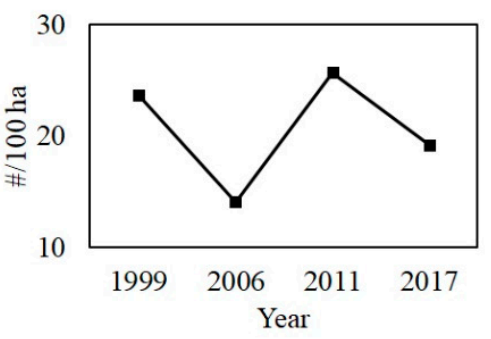

SPLIT

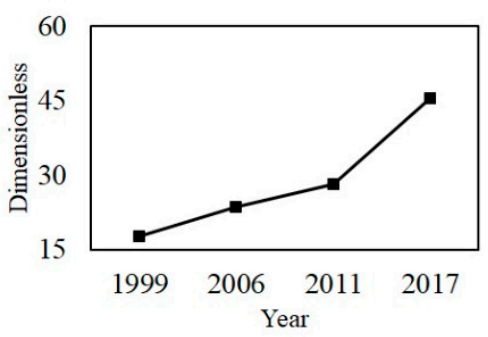

LJ

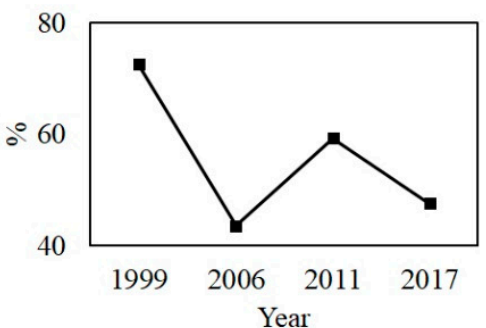

Figure 5. Overall landscape pattern index of ecological land in 1999, 2006, 2011, and 2017. Total Area (TA); Number of patches (NP); Patch Density (PD); Largest Patch Index (LPI); Landscape Shape Index (LSI); Splitting Index (SPLIT); Aggregation Index (AI); Contagion Index (CONTAG); Interspersion Juxtaposition Index (LJI). 


\subsection{Construction of Ecological Landscape Key Area Recognition Index Model}

\subsubsection{Habitat Quality}

We used InVEST 3.7 to determine HQ area and level. The quality of each patch was divided into four levels; with Level 1 being the lowest and Level 4 the highest (see Figure 6 and Table 7). The result showed that the area of Level 1 and Level 2 accounted for a low proportion, but showed an increasing trend from 1999 to 2017. The land area designated HQ Level 3 was the largest for all research years, exceeding $50 \%$ of the total area. Moreover, the area change of Level 3 and Level 4 fluctuates from 1999 to 2017 .
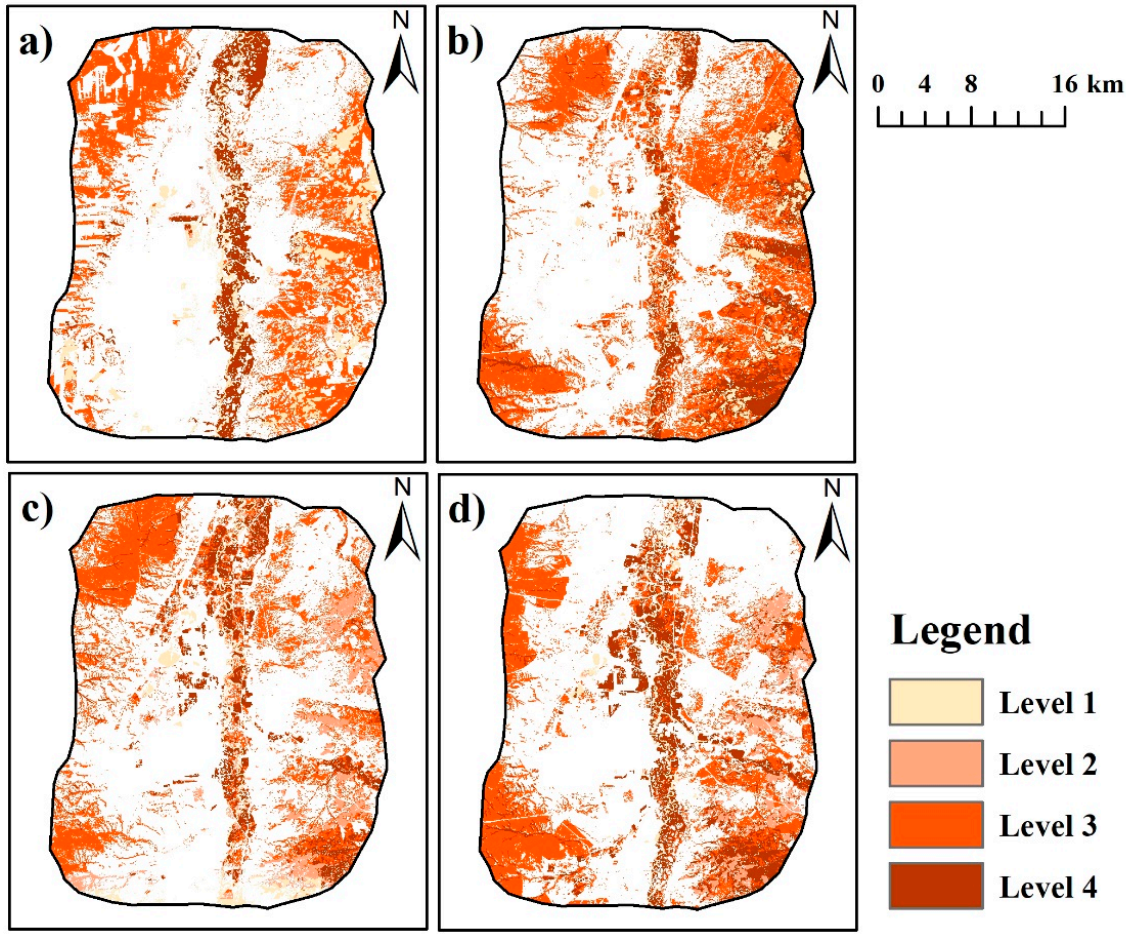

\section{Legend}

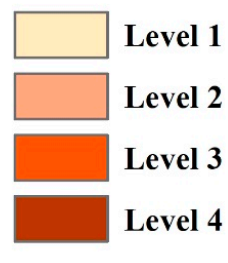

Figure 6. The Habitat Quality levels in 1999 (a), 2006 (b), 2011 (c), and 2017 (d).

Table 7. The area $\left(\mathrm{km}^{2}\right)$ and percentage of Habitat Quality levels in 1999, 2006, 2011, and 2017.

\begin{tabular}{ccccccccc}
\hline & \multicolumn{2}{c}{$\mathbf{1 9 9 9}$} & \multicolumn{2}{c}{$\mathbf{2 0 0 6}$} & \multicolumn{2}{c}{$\mathbf{2 0 1 1}$} & \multicolumn{2}{c}{$\mathbf{2 0 1 7}$} \\
\cline { 2 - 8 } & Area & Percentage & Area & Percentage & Area & Percentage & Area & Percentage \\
\hline Level 1 & 12.36 & $4.11 \%$ & 16.02 & $4.03 \%$ & 16.85 & $5.41 \%$ & 17.71 & $5.46 \%$ \\
Level 2 & 50.11 & $16.65 \%$ & 60.07 & $15.10 \%$ & 59.15 & $18.99 \%$ & 61.69 & $19.00 \%$ \\
Level 3 & 162.20 & $53.90 \%$ & 230.51 & $57.94 \%$ & 154.79 & $49.69 \%$ & 174.09 & $53.62 \%$ \\
Level 4 & 76.26 & $25.34 \%$ & 91.24 & $22.93 \%$ & 80.71 & $25.91 \%$ & 71.16 & $21.92 \%$ \\
\hline
\end{tabular}

Figure 7 shows that wetland and shrubland ecosystem types comprised the majority of HQ Levels 3 and 4, while water and grassland generally ranked lower. The percentage of wetland rated Level 4 was $84.75 \%$ in $1999,83.21 \%$ in $2006,84.62 \%$ in 2011 , and $55.99 \%$ in 2017 . The percentage of shrubland rated Level 3 was $45.37 \%$ in $1999,68.95 \%$ in $2006,83.54 \%$ in 2011 , and $48.35 \%$ in 2017 . During the study period, the Levels 3 area of grassland accounted for about $2 / 3$, indicating that the habitat quality of most grassland was good. Therefore, the patches with higher habitat quality (Levels 3 and 4 ) are located in the wetland of the Yimin River Basin, the shrubland in the east, and some of the grassland patches in the eastern and western regions of the study area. Level 1 and Level 2 are mainly distributed in the water and part of the grassland. The results indicate that both wetland and shrubland play an important role in overall habitat quality. 
1999

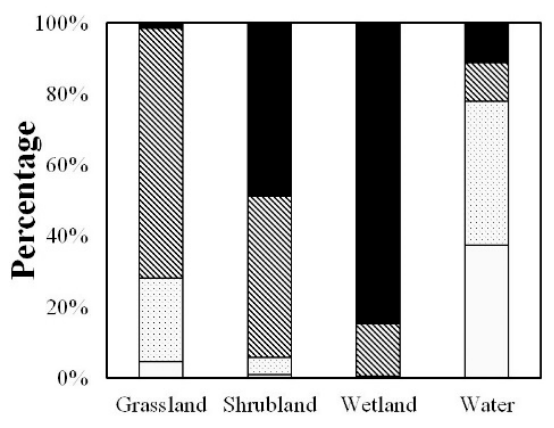

2011

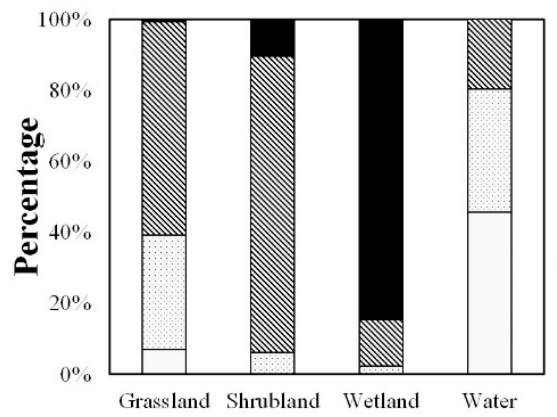

2006

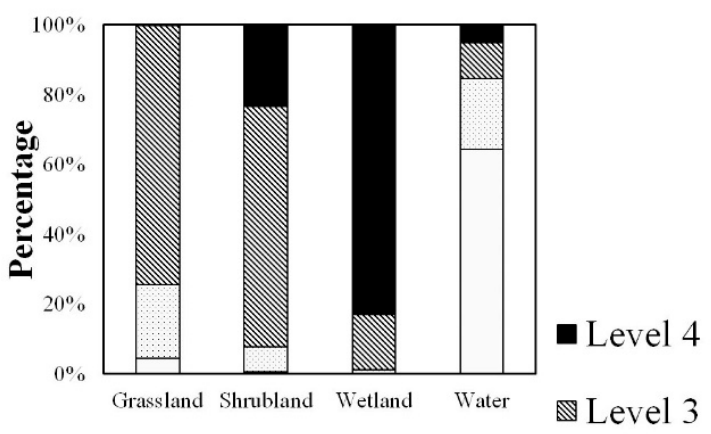

2017

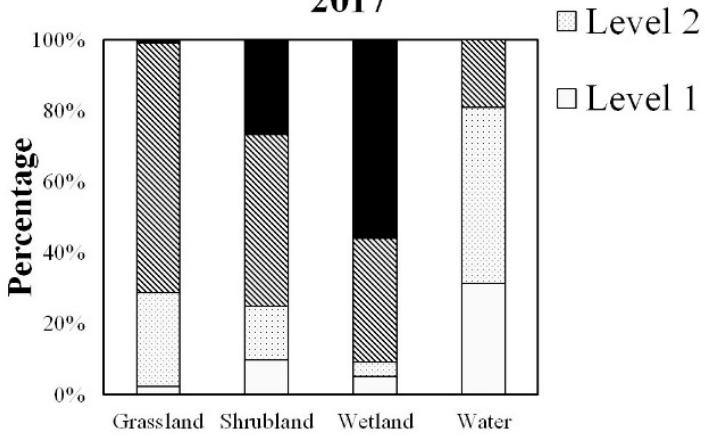

Figure 7. The composition of landscape types for different Habitat Quality levels in 1999, 2006, 2011, and 2017.

\subsubsection{Ecosystem Service Value}

The ESVs of the landscape areas water, bare land, grassland, shrubland, mining land, and built-up land in the study area are shown in Table 8. ESV values for the different types of landscape are wetland, 10,822.77 yuan/ha; shrubland, 5556.62 yuan/ha; grassland, 5387.75 yuan/ha; and water, 4871.55 yuan/ha. Among these, wetland has the highest ESV, with the highest regulation (9048 yuan/ha) and cultural (926.76 yuan/ha) service values. The results indicate that both wetland and shrubland play an important role in overall ESV. Total ESV decreased from 1999 to 2017 with the increase of mining land, built-up land, and bare land.

Table 8. The equivalent factor of Ecosystem Service Value in Yimin coal mine area (yuan/ha).

\begin{tabular}{|c|c|c|c|c|c|c|c|c|}
\hline $\begin{array}{c}\text { Service } \\
\text { Type }\end{array}$ & Indicators & Grassland & Wetland & $\begin{array}{c}\text { Shrub- } \\
\text { land }\end{array}$ & Water & $\begin{array}{l}\text { Built-Up } \\
\text { Land }\end{array}$ & $\begin{array}{c}\text { Mining } \\
\text { Land }\end{array}$ & $\begin{array}{c}\text { Bare } \\
\text { Land }\end{array}$ \\
\hline Supply & food supply & 400.16 & 71.14 & 65.21 & 10.60 & 0 & 0 & 1.05 \\
\hline \multirow{4}{*}{ Regulation } & atmospheric regulation & 93.33 & 476.23 & 853.65 & 0 & 0 & 0 & 0 \\
\hline & climate regulation & 95.38 & 2677.54 & 804.25 & 48.74 & 0 & 0 & 0 \\
\hline & waste disposal & 2370.46 & 2845.50 & 339.88 & 1926.59 & 0 & -260.38 & 1.05 \\
\hline & soil conservation & 123.83 & 393.23 & 794.37 & 1.05 & 0 & 0 & 2.12 \\
\hline Support & biodiversity & 120.78 & 729.16 & 891.19 & 263.88 & 0 & 0 & 36.03 \\
\hline
\end{tabular}

Figure 8 shows the distribution of different levels of ESV. The results indicate that the wetland in the Yimin River Basin and the shrubland in the eastern region of the study area have the highest ESV, while the water and grassland have the lowest. Over the duration of the study period, the area land 
classified as Level 4 and Level 1 increased by a total of $76.64 \%$ and $79.62 \%$, respectively, while the area of classified as Level 3 and Level 2 decreased by a total of $17.00 \%$ and $11.89 \%$, respectively (see Table 9). Land ranked Level 2 covers the largest percentage of area, accounting for $62.47 \%, 66.05 \%, 48.73 \%$, and $51.02 \%$ of the total area of ecological land in 1999, 2006, 2011, and 2017, respectively. The second largest area is of land ranked Level 4 , which accounted for $20.08 \%, 25.27 \%, 27.85 \%$, and $32.88 \%$ of the total area of ecological land in 1999, 2006, 2011, and 2017, respectively.

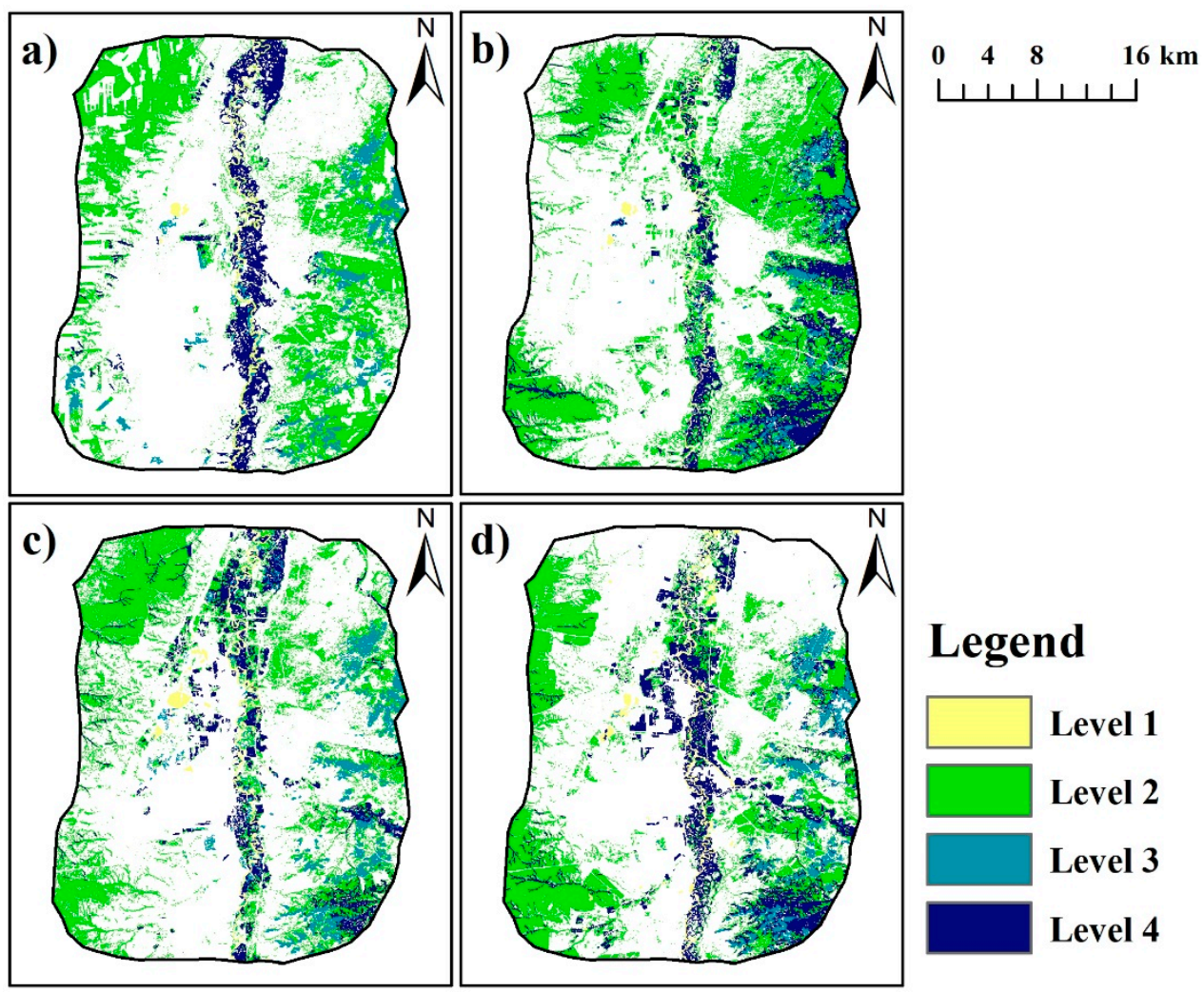

Figure 8. The levels of Ecosystem Service Value in 1999 (a), 2006 (b), 2011 (c), and 2017 (d).

Table 9. The area $\left(\mathrm{km}^{2}\right)$ and percentage of Ecosystem Service Value levels in 1999, 2006, 2011, and 2017.

\begin{tabular}{ccccccccc}
\hline & \multicolumn{2}{c}{$\mathbf{1 9 9 9}$} & \multicolumn{2}{c}{$\mathbf{2 0 0 6}$} & \multicolumn{2}{c}{$\mathbf{2 0 1 1}$} & \multicolumn{2}{c}{$\mathbf{2 0 1 7}$} \\
\cline { 2 - 8 } & Area & Percentage & Area & Percentage & Area & Percentage & Area & Percentage \\
\hline Level 1 & 8.98 & $2.98 \%$ & 6.83 & $1.72 \%$ & 13.76 & $4.42 \%$ & 16.13 & $4.97 \%$ \\
Level 2 & 187.98 & $62.47 \%$ & 262.76 & $66.05 \%$ & 151.78 & $48.73 \%$ & 165.63 & $51.02 \%$ \\
Level 3 & 43.53 & $14.47 \%$ & 27.73 & $6.97 \%$ & 59.19 & $19.00 \%$ & 36.13 & $11.13 \%$ \\
Level 4 & 60.44 & $20.08 \%$ & 100.52 & $25.27 \%$ & 86.76 & $27.85 \%$ & 106.76 & $32.88 \%$ \\
\hline
\end{tabular}

\subsubsection{Importance of Patch Connectivity}

The results of the Importance of Patch Connectivity (IPC) analysis revealed that the average proportion of area covered by Level $4(55.61 \%)$ and Level $1(24.98 \%)$ was relatively large, while that of Level $3(6.38 \%)$ and Level $2(13.03 \%)$ was relatively small (Figure 9 and Table 10). The land changed at different levels of IPC fluctuated from 1999 to 2017. Compared with 1999 and 2017, all the other three levels increased except for Level 2. Thereinto, the area of Level 1 land increased by $24.28 \mathrm{~km}^{2}$ from 1999 to 2017, accounting for 30.82\% of the area in 1999. The area of Level 2 land decreased from $77.45 \mathrm{~km}^{2}$ in 1999 to 2017, accounting for $73.19 \%$ of the area in 1999. The area of Level 3 land increased from $7.88 \mathrm{~km}^{2}$ in 1999 to 2017, accounting for $35.79 \%$ of the area in 1999. Furthermore, the area of Level 4 land increased from $69.02 \mathrm{~km}^{2}$ in 1999 to 2017, accounting for $73.19 \%$ of the area in 1999. 

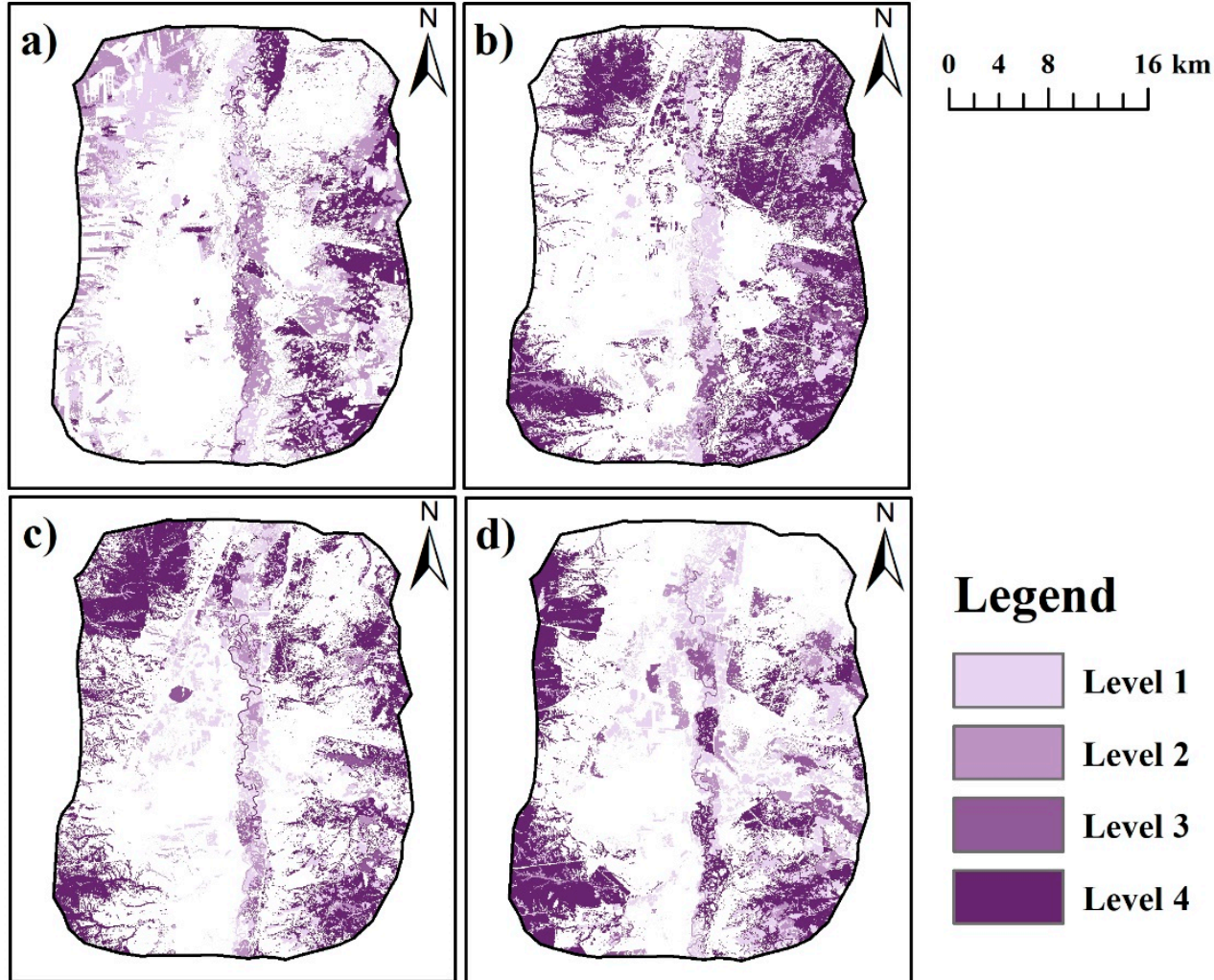

\section{Legend}

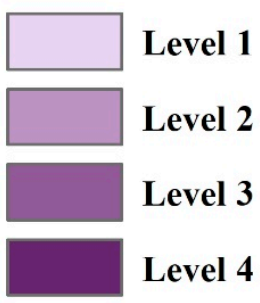

Figure 9. The levels of Importance of Patch Connectivity in 1999 (a), 2006 (b), 2011 (c), and 2017 (d).

Table 10. The area $\left(\mathrm{km}^{2}\right)$ and percentage of Importance of Patch Connectivity levels in 1999, 2006, 2011, and 2017.

\begin{tabular}{ccccccccc}
\hline & \multicolumn{2}{c}{$\mathbf{1 9 9 9}$} & \multicolumn{2}{c}{$\mathbf{2 0 0 6}$} & \multicolumn{2}{c}{$\mathbf{2 0 1 1}$} & \multicolumn{2}{c}{$\mathbf{2 0 1 7}$} \\
\cline { 2 - 8 } & Area & Percentage & Area & Percentage & Area & Percentage & Area & Percentage \\
\hline Level 1 & 78.79 & $26.18 \%$ & 79.20 & $19.91 \%$ & 72.43 & $23.25 \%$ & 103.07 & $31.75 \%$ \\
Level 2 & 105.82 & $35.16 \%$ & 19.20 & $4.83 \%$ & 20.59 & $6.61 \%$ & 28.37 & $8.74 \%$ \\
Level 3 & 22.02 & $7.32 \%$ & 17.06 & $4.29 \%$ & 16.13 & $5.18 \%$ & 29.90 & $9.21 \%$ \\
Level 4 & 94.30 & $31.34 \%$ & 282.39 & $70.98 \%$ & 202.35 & $64.96 \%$ & 163.32 & $50.31 \%$ \\
\hline
\end{tabular}

The areas with higher IPC values are mainly located in the shrubland in the eastern part of the study area, the grassland in the northwestern and southwestern portions, and the centrally located wetland, while IPC values for water and the grassland near the human activity are relatively low. During 1999 to 2017, the IPC of the grassland in the southwest gradually emerged, indicating that the ecological land in this area gradually had better connectivity. Furthermore, there has been a consistently higher IPC over the four study periods for the shrubland and grassland located in the southeastern part of the study area. The results show that forest land and grassland far from human activity are especially important to IPC, while bodies of water play a lesser role.

\subsection{Recognition of Landscape Key Areas}

The results of comprehensive quality evaluation maps of patches (CQEMP) are shown in Figure 10 and Table 11. The results showed that the largest area of ecological land was categorized as Level 3 , accounting for $36.51 \%, 74.19 \%, 65.82 \%$, and $53.67 \%$ of total ecological land in $1999,2006,2011$, and 2017, respectively. 

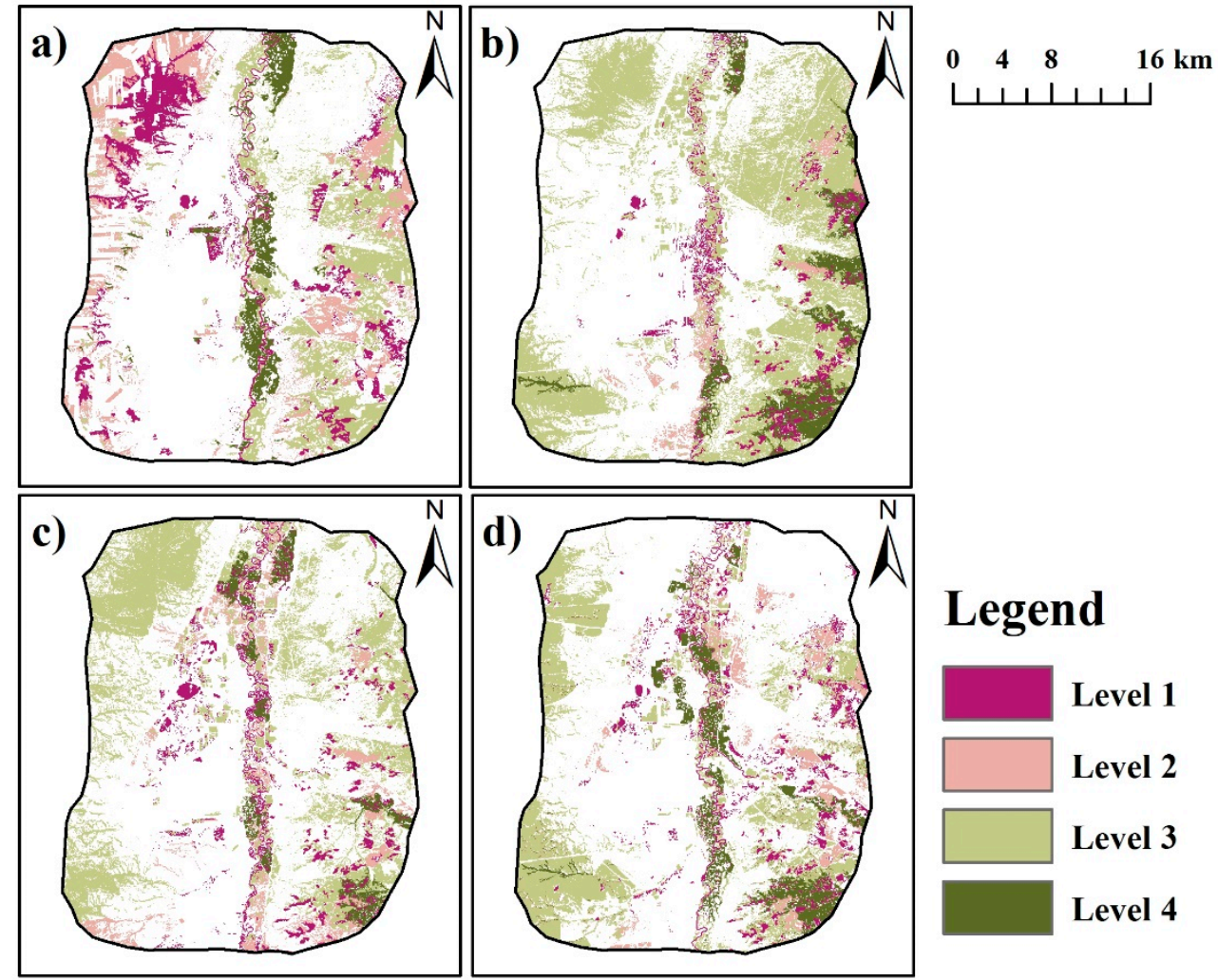

\section{Legend}

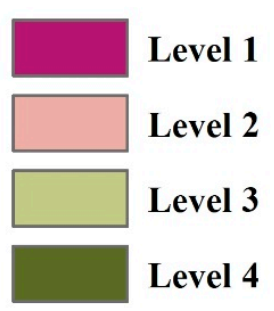

Figure 10. The comprehensive quality evaluation maps of patches (CQEMP) in 1999 (a), 2006 (b), 2011 (c), and 2017 (d).

Table 11. The area $\left(\mathrm{km}^{2}\right)$ and percentage of comprehensive quality evaluation maps of patches (CQEMP) in 1999, 2006, 2011, and 2017.

\begin{tabular}{ccccccccc}
\hline & \multicolumn{2}{c}{$\mathbf{1 9 9 9}$} & \multicolumn{2}{c}{$\mathbf{2 0 0 6}$} & \multicolumn{2}{c}{$\mathbf{2 0 1 1}$} & \multicolumn{2}{c}{$\mathbf{2 0 1 7}$} \\
\cline { 2 - 8 } & Area & Percentage & Area & Percentage & Area & Percentage & Area & Percentage \\
\hline Level 1 & 73.81 & $24.53 \%$ & 38.93 & $9.79 \%$ & 45.48 & $14.60 \%$ & 50.71 & $15.62 \%$ \\
Level 2 & 83.38 & $27.71 \%$ & 14.75 & $3.71 \%$ & 35.30 & $11.33 \%$ & 44.99 & $13.86 \%$ \\
Level 3 & 109.86 & $36.51 \%$ & 295.17 & $74.19 \%$ & 205.04 & $65.82 \%$ & 174.25 & $53.67 \%$ \\
Level 4 & 33.88 & $11.26 \%$ & 49.00 & $12.32 \%$ & 25.67 & $8.24 \%$ & 54.70 & $16.85 \%$ \\
\hline
\end{tabular}

The CQEMPs for 1999, 2006, 2011, and 2017 are superimposed and graded, as shown in Figure 11a. By extracting Very Important Patch (VIMP), Important Patch (IMP) and General Patch (GEP) as ecological sources, the landscape key area recognition results could be obtained, comprising approximately $177.35 \mathrm{~km}^{2}$ in Figure $11 \mathrm{~b}$.

Results of the extraction of Landscape Key Area (LKA) are superimposed on the landscape types of 2017 (Table 12). The results showed that $74.12 \%$ of the wetlands, $54.86 \%$ of the shrublands, and $15.82 \%$ of the grasslands were extracted as LKA in 2017. Landscape types that comprised the LKA are mostly grassland $(47.37 \%)$, wetland $(40.27 \%)$, and shrubland $(11.88 \%)$, indicating that landscape type is highly correlated with its value as a landscape key area. Therefore, the extracted LKA could be regarded as ecological sources. The LKAs are the important ecological functional areas and the core components of the ecosystem with little human disturbance. 


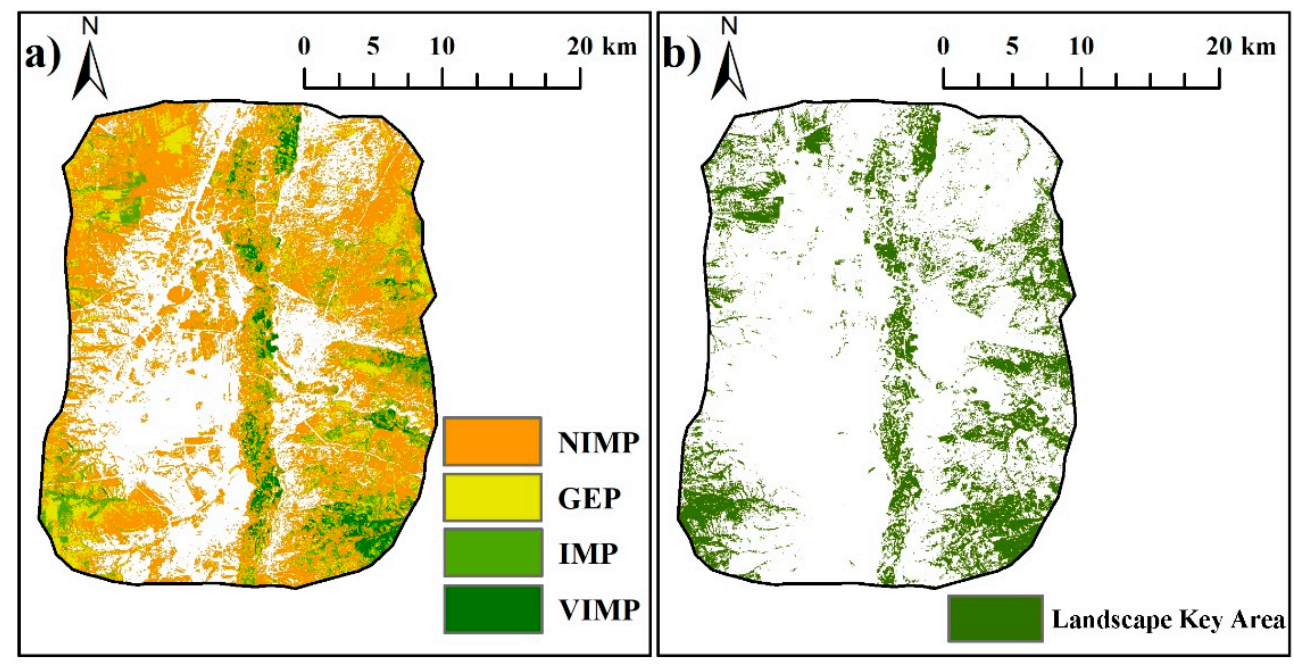

Figure 11. Grade level assigned to ecological land (a) and ecological source (b).

Table 12. Statistics information of ecological source.

\begin{tabular}{ccccc}
\hline & Wetland & Shrub & Grassland & Water \\
\hline Area $\left(\mathrm{km}^{2}\right)$ & 71.41 & 19.82 & 84.01 & 2.11 \\
Percentage of the Ecological Source & $40.27 \%$ & $11.18 \%$ & 47.37 & 1.19 \\
Percentage of the total area for Landscape Type & $74.12 \%$ & $54.86 \%$ & $15.82 \%$ & 16.07 \\
\hline
\end{tabular}

\section{Discussion}

\subsection{Analyzation of Results for Recognition of Ecological Landscape Key Area}

Large open-pit coalmines located in arid and semi-arid steppe areas lead to huge costs in terms of environmental damages which are required to be reclaimed. However, some of the environmental costs can be reduced by integrating local landscape design such as grassland, shrubland, and wetland within the damaged area by optimizing the ecological structure to protect landscape integrity.

Although current research mostly focuses on ecological corridors and ecological security patterns [55], they largely overlook the importance of LKA. This paper employs a recognition model based on remote sensing data from the Landsat $5 \mathrm{TM}$ and Landsat 8 OLI of the Yimin open-pit coal mine of Inner Mongolia. The distribution of the LKA and ecological sources are determined by utilizing HQ, IPC, and ESV as indices.

During the study period, HQ shows first an increasing and then a decreasing trend. The areas with relatively low HQ index values were mainly distributed in the Yimin River Basin and some of the grassland areas. The Yimin open-pit coalmine developed rapidly from 1999 to 2017, causing a continuously decreasing trend in HQ.

Overall, the effects of open-pit mining on biodiversity and habitat quality are lasting. As similar studies report [30,56], open-pit mining has many serious consequences for ecosystems, including surface soil stripping, habitat degradation, and landscape fragmentation. The excavation, human occupation, and wastes disposal associated with mines reduces and fragments healthy landscape patches, decreasing connectivity, and leading to habitat islands of diminished size. These seriously hinder the proliferation and circulation of specie [41]. In terms of landscape connectivity, the ecological land with the highest patch connectivity is dominated by the large areas of eastern shrublands and western grasslands, while the wetlands in the central Yimin River Basin have poor connectivity. However, with the expansion of infrastructures, built-up land, coalmine, and other factors, the landscape is severely fragmenting. Interestingly, the area of grassland in the western region was lower in 1999, although there was no large-scale construction in that year. Some authors believe that 
transitional grazing restricts grassland biodiversity to a certain extent, which might be a factor in the degraded grasslands of 1999 [42,57].

Open-pit mining and consequent landscape changes have caused many socio-economic and environmental problems through the overall deterioration of the local environment and ecosystem services [58]. Since the mine's opening, the ESV of the surrounding area has decreased substantially and, if the trend continues, it may negatively affect the quality of life available to residents in the area. Some studies have found that ESV decreases in areas subjected to mining activity [10]. Therefore, in the face of uncertainty regarding changes in ecosystem service and function in coal mine areas, a ranking system for the ESV of ecological land is needed for ecosystem management. In this study, we divided the ESV values of ecological land (wetland, shrubland, grassland, water) to facilitate the superposition of HQ, ESV, and IPC in the later stage, while the method of division could be flexible.

Figure $11 \mathrm{~b}$ and Table 12 show that the ecological source area is $177.35 \mathrm{~km}^{2}$, accounting for $20.01 \%$ of the total studied area. Among all landscape types, $74.12 \%$ of wetland, $54.86 \%$ of shrubland, $15.82 \%$ of grassland, and $16.07 \%$ of water were extracted as ecological sources. Ecological sources were mainly distributed in the wetlands of the Yimin River Basin, the shrubland in the east, and the grasslands in the northwest and southwest regions, which may reflect the spatial agglomeration characteristics of biodiversity, water conservation, and soil conservation of multiple ecosystem services.

The study area is located in Greater Khingan Range, an important forestry base in China that is rich in virgin forests. The main trees are Larix gmelinii, Pinus sylvestris var. mongolica, Betula platyphylla Suk, and Quercus mongolica. This region is also very rich in animal species including many types of birds, mammals, and amphibians, making the value of ecosystem services here very high.

This important ecological source guarantees the regional ecological security. The existing Honghuaerji-Yimin-River National Wetland Park in Inner Mongolia (Pilot), one of the seven National Wetland Parks (Pilot) approved by China within the study area, is located within an area we designated as an ecological source. This offers some evidence that our spatial recognition results are consistent with real-world conditions.

\subsection{Advantages of the Ecological Landscape Key Area Recognition Index Model}

In this study, a landscape key area recognition model was established through a comprehensive method. This model has several advantages. First, the model's indices of HQ, ESV, and IPC are all based on Landsat 5 TM and Landsat 8 OLI. Therefore, the material can be easily obtained and the model can be easily constructed in order to recognize and identify the LKA. Second, as shown in Figure 10, the model is flexible in temporal scale, allowing variation of key time nodes according to different requirements. This feature will be useful when recognizing LKA of other open-pit coalmine areas by flexible construction of a recognition index system according to specific spatial characteristics. Third, this model is suitable for the semi-arid steppe, it is very hard to improve the entire ecological area for its large area. Therefore, it is feasible to recognize ecological LKA as ecological sources. In this way, the model provides a new means of recognizing ecological sources around open-pit coalmines in semi-arid steppes.

\subsection{Suggestions and Research Prospects of Recognition for Ecological Landscape Key Area}

The restoration of steppe open-pit coal mine areas centers on grassland as the starting point with the aim of recognizing key areas of ecological processes and functions to target for restoration.

Open pit coal exploitation has affected the sustainability of steppes. Furthermore, open-pit coal mines are highly vulnerable to natural disasters such as landslides and soil erosion due to slope deformation and dumping. Moreover, because biodiversity does not tend to thrive in a single geomorphic environment, the habitat fragmentation associated with mining limits ecological restoration and resistance on desertification and erosion efficiency. All these problems must be considered in any future landscape planning among the Yimin open-pit coalmine area. Geological stability and ecological sustainability must be reclaimed within the effect areas of open pit coalmine. 
In summary, we advocate that the government should reinforce the protections of ecological sources and strictly control regional urbanization and coalmine utilization. In particular, the wetlands of the Yimin River Basin and the shrubland in the eastern region of our study area require special protection in order to ensure species diversity and ecological flow throughout the wider landscape. Further, ecological sources should be rationally utilized with consideration of environmental integrity, while ecological corridors and landscape ecological security patterns should be constructed to conserve landscape-level stability. In this way, functions of vulnerable ecosystem can better be enhanced and maintained.

Although our recognition results are consistent with the actual conditions, our methods and understanding are still in development. Therefore, the results could be further quantified in combination with FRAGSTATS to obtain some more meaningful explanations on the quantity and spatial distribution of ecological importance in the future. Several problems facing the ecological health of open-pit coalmine areas need further study. For example, the indices used in this study are based on remote sensing images, which are easily and dynamically captured in real time. However, ecological aspects in finer scales, such as animal, plant, and microbial community dynamics, along with hydrological, geological, and atmospheric factors should also be considered. In addition, dynamic changes in human health, public governance, social stability, and other factors in the study area are important subjects of investigation, such as relationships between mining and ecological as well as socio-economic factors over an extended temporal scale. The objective of ecological restoration in mining areas is to conserve a healthy landscape-level ecology and to establish a harmonious relationship between humans and nature [59].

\section{Conclusions}

Open-pit coal mining is prone to causing ecological problems, such as soil erosion and other disturbances which damage fragile ecosystems. Large-scale restoration of open-pit coal mines in semi-arid steppes will entail huge labor and environmental capital costs. Therefore, the recognition of LKA can effectively identify important ecological land patches as ecological sources, which are important links in the continuity between ecosystem services and ecological protection strategies. Because recognizing LKA is a spatiotemporal distribution problem, the comprehensive application of RS and GIS is an effective means by which to quickly obtain and accurately analyze relevant data in order to dynamically monitor changes in different landscape indices.

This study used the Yimin coal mine area as an example for establish a landscape key area recognition model by selecting Habitat Quality, Importance of Patch Connectivity, and Ecosystem Service Value as spatiotemporal indices. The model proposed in this study takes into account the characteristics of open-pit coal mine in semi-arid steppes, such as grassland degradation, high heterogeneity of the ecosystem services, and landscape fragmentation. This model has the advantage of being flexible and open to identifying LKA of other coal mine sites because the recognition index system can be flexibly constructed according to the characteristics of each research area.

Our research results show that (1) LKA in the Yimin coal mine area cover $177.35 \mathrm{~km}^{2}$. This accounts for $20.01 \%$ of the total study area and is mainly distributed in the wetland of the Yimin River Basin and the shrubland in the eastern portion of the study area. (2) The landscape types of LKA are mostly grassland (47.37\%), wetland (40.27\%), and shrubland (11.88\%), indicating that landscape type correlates strongly with its value as a landscape key area. Further, LKA can be regarded as ecological sources.

The Yimin coal mine area is rich in forest and steppe resources, which offer important contributions to the maintenance of ecosystem stability and environmental quality. However, ecological connectivity is affected by landscape fragmentation, which is intensified by human activities such as coal mining. Therefore, the question of how to conserve existing ecological sources has become an important part of the ecological planning in the Yimin coal mine area. This study will provide a reference for recognizing LKA in semi-arid steppe coal mine areas. 
Author Contributions: S.W. determine the research principles; H.Y. mainly accomplish the writing and contributed to discussion and editing; Both J.H. and H.Y. conducted the research and provided guidance on the technical research route; C.J., H.Y., and J.H. contributed to image processing and data analyses. All authors have read and agreed to the published version of the manuscript.

Funding: This work was funded by the "China Fundamental Research Funds for the Central Universities (Grant No. 2019XKQYMS82)", the projects National Natural Science Foundation of China (Grant No. U1710120) and the National Key Research and Development Project (Grant No. 2016YFC0501107).

Acknowledgments: The authors thank the study participants and teachers for their cooperation and support. We thank the reviewer and editor for good comments and hard work. We also thank the National Natural Science Foundation of China and China Ministry for Science and Technology for their financial support.

Conflicts of Interest: The authors declare no conflict of interest.

\section{References}

1. Wang, W.; Hao, W.; Bian, Z.; Lei, S.; Wang, X.; Sang, S.; Xu, S. Effect of coal mining activities on the environment of Tetraena mongolica in Wuhai, Inner Mongolia, China-A geochemical perspective. Int. J. Coal Geol. 2014, 132, 94-102. [CrossRef]

2. Miao, Z.; Marrs, R. Ecological restoration and land reclamation in open-cast mines in Shanxi Province, China. J. Environ. Manag. 2000, 59, 205-215. [CrossRef]

3. Demirel, N.; Emil, M.K.; Duzgun, H.S. Surface coal mine area monitoring using multi-temporal high-resolution satellite imagery. Int. J. Coal Geol. 2011, 86, 3-11. [CrossRef]

4. Erener, A. Remote sensing of vegetation health for reclaimed areas of Seyitömer open cast coal mine. Int. J. Coal Geol. 2011, 86, 20-26. [CrossRef]

5. Bian, Z.; Lei, S.; Inyang, H.I.; Chang, L.; Zhang, R.; Zhou, C.; He, X. Integrated method of RS and GPR for monitoring the changes in the soil moisture and groundwater environment due to underground coal mining. Environ. Geol. 2009, 57, 131-142. [CrossRef]

6. Lei, S.; Ren, L.; Bian, Z. Time-space characterization of vegetation in a semiarid mining area using empirical orthogonal function decomposition of MODIS NDVI time series. Environ. Earth Sci. 2016, 75, 516. [CrossRef]

7. Bohrer, S.L.; Limb, R.F.; Daigh, A.L.; Volk, J.M.; Wick, A.F. Fine and Coarse-Scale Patterns of Vegetation Diversity on Reclaimed Surface Mine-land Over a 40-Year Chronosequence. Environ. Manag. 2017, 59, 431-439. [CrossRef]

8. Józefowska, A.; Pietrzykowski, M.; Woś, B.; Cajthaml, T.; Frouz, J. The effects of tree species and substrate on carbon sequestration and chemical and biological properties in reforested post-mining soils. Geoderma 2017, 292, 9-16. [CrossRef]

9. Ahirwal, J.; Maiti, S.K. Development of Technosol properties and recovery of carbon stock after 16 years of revegetation on coal mine degraded lands, India. Catena 2018, 166, 114-123. [CrossRef]

10. Larondelle, N.; Haase, D. Valuing post-mining landscapes using an ecosystem services approach-An example from Germany. Ecol. Indic. 2012, 18, 567-574. [CrossRef]

11. Bian, Z.; Lu, Q. Ecological effects analysis of land use change in coal mining area based on ecosystem service valuing: A case study in Jiawang. Environ. Earth Sci. 2013, 68, 1619-1630. [CrossRef]

12. Kobayashi, H.; Watando, H.; Kakimoto, M. A global extent site-level analysis of land cover and protected area overlap with mining activities as an indicator of biodiversity pressure. J. Clean. Prod. 2014, 84, 459-468. [CrossRef]

13. Cao, Y.; Zhou, W.; Wang, J.; Yuan, C. Spatial-temporal Pattern and Differences of Land Use Changes in the Three Gorges Reservoir Area of China during 1975-2005. J. Mt. Sci. 2011, 8, 551-563. [CrossRef]

14. Qian, D.; Yan, C.; Xing, Z. Monitoring coal mine changes and their impact on landscape patterns in an alpine region: A case study of the Muli coal mine in the Qinghai-Tibet Plateau. Environ. Monit. Assess. 2017, 11, 559. [CrossRef] [PubMed]

15. Yu, L.; García, A.; Chivas, A.R.; Tibby, J.; Kobayashi, T.; Haynes, D. Ecological change in fragile floodplain wetland ecosystems, natural vs human influence: The Macquarie Marshes of eastern Australia. Aquat. Bot. 2015, 120, 39-50. [CrossRef]

16. Cao, Y.; Bai, Z.; Zhou, W.; Zhang, X. Characteristic analysis and pattern evolution on landscape types in typical compound area of mine agriculture urban in Shanxi Province, China. Environ. Earth Sci. 2016, 75, 1-15. [CrossRef]

17. Zhao, B.; Guo, D.; Shao, H.; Bai, Z. Investigating the population structure and spatial pattern of restored forests in an opencast coal mine, China. Environ. Earth Sci. 2017, 20, 679. [CrossRef] 
18. Doley, D.; Audet, P.; Mulligan, D.R. Examining the Australian context for post-mined land rehabilitation: Reconciling a paradigm for the development of natural and novel ecosystems among post-disturbance landscapes. Agric. Ecosyst. Environ. 2012, 163, 85-93. [CrossRef]

19. Mwitwa, J.; German, L.; Muimba-Kankolongo, A.; Puntodewo, A. Governance and sustainability challenges in landscapes shaped by mining: Mining-forestry linkages and impacts in the Copper Belt of Zambia and the DR Congo. For. Policy Econ. 2012, 25, 19-30. [CrossRef]

20. Wu, Q.; Pang, J.; Qi, S.; Li, Y.; Han, C.; Liu, T.; Huang, L. Impacts of coal mining subsidence on the surface landscape in Longkou city, Shandong Province of China. Environ. Earth Sci. 2009, 59, 783-791.

21. Hüttl, R.F.; Gerwin, W. Landscape and ecosystem development after disturbance by mining. Ecol. Eng. 2005, 24, 1-3. [CrossRef]

22. Biemelt, D.; Schapp, A.; Grünewald, U. Hydrological observation and modelling relationship for the determination of water budget in Lusatian post-mining landscape. Phys. Chem. Earth Parts A/B/C 2011, 36, 3-18. [CrossRef]

23. Skaloš, J.; Kašparová, I. Landscape memory and landscape change in relation to mining. Ecol. Eng. 2012, 43, 60-69. [CrossRef]

24. Misthos, L.; Messaris, G.; Damigos, D.; Menegaki, M. Exploring the perceived intrusion of mining into the landscape using the fuzzy cognitive mapping approach. Ecol. Eng. 2017, 101, 60-74. [CrossRef]

25. Du, S.; Xiong, Z.; Wang, Y.; Guo, L. Quantifying the multilevel effects of landscape composition and configuration on land surface temperature. Remote Sens. Environ. 2016, 178, 84-92. [CrossRef]

26. Yang, Y.; Erskine, P.D.; Lechner, A.M.; Mulligan, D.; Zhang, S.; Wang, Z. Detecting the dynamics of vegetation disturbance and recovery in surface mining area via Landsat imagery and LandTrendr algorithm. J. Clean. Prod. 2018, 178, 353-362. [CrossRef]

27. Estoque, R.C.; Murayama, Y.; Myint, S.W. Effects of landscape composition and pattern on land surface temperature: An urban heat island study in the megacities of Southeast Asia. Sci. Total Environ. 2017, 577, 349-359. [CrossRef]

28. Dulias, R. Landscape planning in areas of sand extraction in the Silesian Upland, Poland. Landsc. Urban Plan. 2010, 95, 91-104. [CrossRef]

29. Adriaensen, F.; Chardon, J.P.; De Blust, G.; Swinnen, E.; Villalba, S.; Gulinck, H.; Matthysen, E. The application of 'least-cost' modelling as a functional landscape model. Landsc. Urban Plan. 2003, 64, 233-247. [CrossRef]

30. Gangloff, M.M.; Perkins, M.; Blum, P.W.; Walker, C. Effects of Coal Mining, Forestry, and Road Construction on Southern Appalachian Stream Invertebrates and Habitats. Environ. Manag. 2015, 55, 702-714. [CrossRef]

31. Bayliss, J.L.; Simonite, V.; Thompson, S. The use of probabilistic habitat suitability models for biodiversity action planning. Agric. Ecosyst. Environ. 2005, 108, 228-250. [CrossRef]

32. Costanza, R.; D'Arge, R.; Groot, R.; Farber, S.; Grasso, M.; Hannon, B.; Limburg, K.; Naeem, S.; O’Neill, R.V.; Paruelo, J.; et al. The value of the world's ecosystem services and natural capital. Ecol. Econ. 1997, 25, 3-15. [CrossRef]

33. Xiang, Y.; Meng, J.; You, N.; Chen, P.; Yang, H. Spatio-temporal Analysis of Anthropogenic Disturbances on Landscape Pattern of Tourist Destinations: A case study in the Li River Basin, China. Sci. Rep. 2019, 9, 19285. [CrossRef]

34. Daniela, R.; Marco, V. Land use and landscape pattern changes driven by land reclamation in a coastal area: The case of Volturno delta plain, Campania Region, southern Italy. Environ. Earth Sci. 2017, 76, 694. [CrossRef]

35. Mi, J.; Yang, Y.; Zhang, S.; An, S.; Hou, H.; Hua, Y.; Chen, F. Tracking the Land Use/Land Cover Change in an Area with Underground Mining and Reforestation via Continuous Landsat Classification. Remote Sens. 2019, 11, 1719. [CrossRef]

36. Duan, C.; Wu, L.; He, L.; Wang, S. Spatio-temporal distribution pattern of vegetation coverage in Junggar Basin, Xinjiang. Acta Ecol. Sin. 2016, 36, 72-76. [CrossRef]

37. Lakes, T.; Müller, D.; Krüger, C. Cropland change in southern Romania: A comparison of logistic regressions and artificial neural networks. Landsc. Ecol. 2009, 9, 1195-1206. [CrossRef]

38. Baeza, A.; Bouma, M.J.; Dobson, A.P.; Dhiman, R.; Srivastava, H.C.; Pascual, M. Climate forcing and desert malaria: The effect of irrigation. Malar. J. 2011, 10, 190. [CrossRef]

39. Yan, H.; Zhan, J.; Liu, B.; Yuan, Y. Model Estimation of Water Use Efficiency for Soil Conservation in the Lower Heihe River Basin, Northwest China during 2000-2008. Sustainability 2014, 6, 6250-6266. [CrossRef] 
40. Peng, J.; Zhao, M.; Guo, X.; Pan, Y.; Liu, Y. Spatial-temporal dynamics and associated driving forces of urban ecological land: A case study in Shenzhen City, China. Habitat Int. 2017, 60, 81-90. [CrossRef]

41. Wu, Z.; Lei, S.; He, B.; Bian, Z.; Wang, Y.; Lu, Q.; Peng, S.; Duo, L. Assessment of Landscape Ecological Health: A CaseStudy of a Mining City in a Semi-Arid Steppe. Int. J. Environ. Res. Public Health 2019, 16, 752. [CrossRef] [PubMed]

42. Wang, Z.; Deng, X.; Song, W.; Li, Z.; Chen, J. What is the main cause of grassland degradation? A case study of grassland ecosystem service in the middle-south Inner Mongolia. Catena 2017, 150, 100-107. [CrossRef]

43. Li, X.; Lu, L.; Cheng, G.; Xiao, H. Quantifying landscape structure of the Heihe River Basin, north-west China using FRAGSTATS. J. Arid Environ. 2001, 48, 521-535. [CrossRef]

44. McGarigal, K.; Marks, B. FRAGSTATS: Spatial Pattern Analysis Program for Quantifying Landscape Structure Reference Manual; Forest Science Department Oregon State University: Corvallis, OR, USA, 1994; p. 62.

45. Chu, L.; Sun, T.; Wang, T.; Li, Z.; Cai, C. Evolution and Prediction of Landscape Pattern and Habitat Quality Based on CA-Markov and InVEST Model in Hubei Section of Three Gorges Reservoir Area (TGRA). Sustainability 2018, 10, 3854. [CrossRef]

46. Terrado, M.; Sabater, S.; Chaplin-Kramer, B.; Mandle, L.; Ziv, G.; Acuña, V. Model development for the assessment of terrestrial and aquatic habitat quality in conservation planning. Sci. Total Environ. 2016, 540, 63-70. [CrossRef] [PubMed]

47. Seabrook, L.; McAlpine, C.; Rhodes, J.; Baxter, G.; Bradley, A.; Lunney, D. Determining range edges: Habitat quality, climate or climate extremes? Divers. Distrib. 2014, 20, 95-106. [CrossRef]

48. Yang, Y.; Wang, K.; Liu, D.; Zhao, X.; Fan, J.; Li, J.; Zhai, X.; Zhang, C.; Zhan, R. Spatiotemporal Variation Characteristics of Ecosystem Service Losses in the Agro-Pastoral Ecotone of Northern China. Environ. Res. Public Health 2019, 16, 1199. [CrossRef] [PubMed]

49. Xie, G.; Zhang, C.; Zhang, C.; Xiao, Y.; Lu, C. The value of ecosystem services in China. Resour. Sci. 2015, 37, 1740-1746.

50. Zhang, M.; Zhou, Y.; Liu, X.; Lu, Z. Ecological landscape regulation approaches in Xilingol, Inner Mongolia: An urban ecosystem services perspective. Int. J. Sustain. Dev. World Ecol. 2017, 24, 401-407. [CrossRef]

51. Qi, K.; Fan, Z.; Ng, N.C.; Wang, X.; Xie, Y. Functional analysis of landscape connectivity at the landscape, component, and patch levels: A case study of Minqing County, Fuzhou City, China. Appl. Geogr. 2017, 80, 64-77. [CrossRef]

52. Blazquez-Cabrera, S.; Bodin, Ö.; Saura, S. Indicators of the impacts of habitat loss on connectivity and related conservation priorities: Do they change when habitat patches are defined at different scales? Ecol. Indic. 2014, 45, 704-716. [CrossRef]

53. Saura, S.; Rubio, L. A common currency for the different ways in which patches and links can contribute to habitat availability and connectivity in the landscape. Ecography 2010, 33, 523-537. [CrossRef]

54. Saura, S.; Torné, J. Conefor Sensinode 2.2: A software package for quantifying the importance of habitat patches for landscape connectivity. Environ. Model. Softw. 2009, 24, 135-139. [CrossRef]

55. Yu, Q.; Yu, Y.; Yue, D.; Wang, J.; Zhang, Q.; Li, N.; Li, Y.; Chen, J. The optimization of urban ecological infrastructure network based on the changes of county landscape patterns: A typical case study of ecological fragile zone located at Deng Kou (Inner Mongolia). J. Clean. Prod. 2017, 163, S54-S67. [CrossRef]

56. Novianti, V.; Marrs, R.H.; Choesin, D.N.; Iskandar, D.T.; Suprayogo, D. Natural regeneration on land degraded by coal mining in a tropical climate: Lessons for ecological restoration from Indonesia. Land Degrad. Dev. 2018, 29, 4050-4060. [CrossRef]

57. Liu, M.; Dries, L.; Heijman, W.; Huang, J.; Zhu, X.; Hu, Y.; Chen, H. The Impact of Ecological Construction Programs on Grassland Conservation in Inner Mongolia, China. Land Degrad. Dev. 2018, 29, 326-336. [CrossRef]

58. Chen, J.; John, R.; Zhang, Y.; Shao, C.; Brown, D.G.; Batkhishig, O.; Amarjargal, A.; Ouyang, Z.; Dong, G.; Wang, D.; et al. Divergences of Two Coupled Human and Natural Systems on the Mongolian Plateau. Bioscience 2015, 65, 559-570. [CrossRef]

59. Lei, K.; Pan, H.; Lin, C. A landscape approach towards ecological restoration and sustainable development of mining areas. Ecol. Eng. 2016, 90, 320-325. [CrossRef]

(C) 2020 by the authors. Licensee MDPI, Basel, Switzerland. This article is an open access article distributed under the terms and conditions of the Creative Commons Attribution (CC BY) license (http://creativecommons.org/licenses/by/4.0/). 